\title{
Íslenskukennsla í Bessastaðaskóla 1806-1846 og á fyrstu árum Reykjavíkurskóla
}

\section{Inngangur ${ }^{1}$}

Fræðimenn hafa bent á að á 19. öld hafi mótast málstaðall sem smám saman hafði áhrif á tungumálið og hefur verið einkenni pess síðan. Nefnd hafa verið mikil áhrif kennslunnar í Bessastaðaskóla og pá einkum áhrif gullaldarpýðinga Sveinbjarnar Egilssonar á Hómerskviðum úr grísku og málvöndunar Hallgríms Scheving í latínupýðingum (Kjartan G. Ottósson 1990:61-65). Skáld og fræðimenn sem paðan komu réðu miklu um próun málsins en lítið hefur verið fjallað um bein áhrif móðurmálskennslu í skólanum.

Íslenska var alla tíð kennd í Bessastaðaskóla en hún stóð sem í skugga stóru greinanna, latínu, grísku og trúfræðigreina, enda var skólinn prestaskóli öðru fremur. Skýrslur um skólastarfið eru heimildir um hvað réði pví að íslenska komst á blað í stundaskránni, hverjir kenndu hana og hvað var kennt en óbeint eru pær líka heimild um pað hvernig starfið á Bessastöðum hafði áhrif á próun málsins á fyrri hluta 19. aldar prátt fyrir „skuggatilveru“ íslenskukennslunnar í skólastarfinu.

Biskupsskjalasafn á Pjóðskjalasafni Íslands (hér eftir Bps.) geymir skýrslur kennara um skólastarfið á Bessastöðum en pær rituðu peir

1 Grein pessi er byggð á BA-ritgerð í íslensku sem fjallaði um niðurstöður athugana á íslenskukennslu í Bessastaðaskóla og á fyrstu árum Reykjavíkurskóla. Verkefnið náđi yfir 50 ára starf skólanna (Alda B. Möller 2014).

Orð og tunga 19 (2017), 1-40. @ Stofnun Árna Magnússonar í íslenskum fræðum, Reykjavík. 
í áratugi og fjölluðu einkum um hvað peir kenndu og hvernig. Safnið geymir einnig umsóknir um skólavist, stundaskrár, próftöflur, vitnisburði um nemendur og fjöldamargt er tengdist rekstri skólans enda voru biskup og stiftamtmaður yfirvöld skólans hérlendis. Flest eru pessi skjöl á dönsku og öll í handriti. Frá stiftsyfirvöldum bárust skýrslurnar til Skólastjórnarráðsins danska sem var yfirvald æðri skóla í danska ríkinu 1805-1848. Skjölin bárust aftur til landsins 1928 og eru vistuð í Pjóðskjalasafni Íslands sem Skjalasafn skólastjórnarmála (hér eftir Sk.). Saman gefa pessi skjalasöfn nokkuð heillega mynd af starfi Bessastaðaskóla en prentaðar skólaskýrslur rektora eru auk pess til frá 1840. Fyrirmæli Skólastjórnarráðsins sem íslenskukennslan byggðist á er svo að finna í bókaflokknum Lovsamling for Island (hér eftir LS 6 og LS 7). Engin gögn nemenda um námið í íslensku var að finna í heimildum um Bessastaðaskóla.

Miklu fjölbreyttara efni um Reykjavíkurskóla er að finna í handritum á Pjóðskjalasafni Íslands. Varðveist hafa lestrarbækur nemenda sem peir skrifuðu sjálfir, námsáætlanir, stundaskrár og skrifleg próf, p. á m. ritgerðir nemenda. Hér verður vitnað til pessara heimilda sem MR-skjalasafnsins. Aðrar meginheimildir frá pessum tíma eru skýrslur rektors.

Athuganir sýndu glöggt að uppistaða íslenskunámsins í Bessastaðaskóla var stílagerð sem í áratugi fólst mest í pýðingum úr dönskum og latneskum lestrarbókum. Vanbúið húsnæði og prengsli stóðu skólanum mjög fyrir prifum í faglegum efnum og ljóst er að íslenskukennslan leið fyrir pessi vandræði. Framfaraöflin leystust úr læðingi pegar hið mikla hús Reykjavíkurskóla reis og skólastarf fluttist pangað 1846. Á fáeinum árum gjörbreyttist aðstaðan til íslenskukennslu, bekkjum fjölgaði og nýir kennarar komu til starfa. Pá festust kennsluaðferðir og kennsluefni í sessi sem fylgdu skólanum áratugum saman eftir pað.

Á fyrsta ári Reykjavíkurskóla var íslenska reyndar enn kennd „,með gamla laginu“, p.e. með gerð stíla, en veturinn 1847-1848 má segja að íslenska hafi loks orðið eiginleg grein í skólastarfi hérlendis pví að pá hófst skipuleg kennsla í íslenskri málfræði og íslenskum bókmenntum. Í stundaskránni fjölgaði pá vikustundum í greininni í tólf með mesta áherslu á íslenskukennslu í neðri bekkjunum en aðalkennari î íslensku fyrstu tvö árin var Sveinbjörn Egilsson, rektor skólans. Önnur tímamót urðu síðan pegar eldhuginn Halldór Kr. Friðriksson gerðist kennari við skólann 1848. Frá byrjun tók hann íslenskukennsluna föstum tökum og kenndi í tæplega hálfa öld en lét af störfum 1895. 
Efni greinarinnar skiptist pannig: Í 2. kafla er stutt yfirlit um Bessastaðaskóla og fjallað um fyrirmæli frá Danmörku sem kennarar áttu að fara eftir. Fram kemur að frá fyrstu árum Bessastaðaskóla átti móðurmálskennsla stuðning danskra yfirvalda og tíðarandinn var henni hagstæður. Í 3. kafla er fjallað um kennara og íslenskukennsluna á Bessastöðum, p.e. heimildir um hvað var kennt og hvernig, pau fjörutíu ár sem pær geyma. Í 4. kafla er sagt frá veru Jónasar Hallgrímssonar skálds í skólanum 1823-1829 og gripið niður í skrif hans í skólablað og brottfararræðu til að bregða ljósi á svipmót texta hans eftir langa veru í skólanum. Í kaflanum er einnig lýsing tveggja annarra pilta á skólalífinu og kennslunni og hvernig hún mótaði málsmekk peirra en minningar peirra voru skrifaðar löngu síðar.

Í 5. kafla víkur sögunni til Reykjavíkurskóla og hefst frásögnin á stuttu yfirliti um fyrstu reglugerðir fyrir skólann en par var skilgreint hvernig kenna skyldi námsgreinina, hvað kennt og hvernig prófað en flest bendir til að par hafi verið tekið mið af móðurmálskennslunni í dönskum skólum. Íslensku skyldi kenna í öllum bekkjum og nemendum lærast að tala hana og rita rétt og kynnast jafnframt bókmenntasögu Íslendinga og helstu ritum. Í 6. kafla er sagt frá fyrstu tveimur árum kennslunnar undir stjórn Sveinbjarnar Egilssonar rektors og lítillega frá málfræðihandritum hans sem hann hefur líklega stuðst við. Par er einnig fjallað um stíla eins nemanda Sveinbjarnar. Í 7. kafla er svo fjallað um kennslu Halldórs Kr. Friðrikssonar, sagt frá námsefni og kennsluaðferðum eins og hann lýsir peim sjálfur og greint frá helstu reglum réttritunar sem við hann er kennd en oftast nefnd skólastafsetningin. Loks er lýst athugun á ritgerðum nemenda sem sýna glöggt hversu fljótt og vel menn tömdu sér reglurnar. Í 8. kafla er samantekt á efninu og nokkur lokaorð.

\section{Svipmynd af Bessastaðaskóla og fyrirmæli yfirvalda um hann}

\subsection{Skólasveinar og kennarar}

Lærða skólanum á Bessastöðum var ætlað að starfa til bráðabirgða í litlu og ófullnægjandi húsnæði en úr peim vanda hans rættist aldrei. Bekkirnir voru tveir pví að fleiri voru skólastofurnar ekki en auk pess voru í húsinu vistarverur nemenda, mötuneyti skólans og íbúð bryta. 
Lokapróf frá skólanum veitti réttindi til prestsembætta og frekara náms í Kaupmannahafnarháskóla en í Bessastaðaskóla átti að kenna fornmálin, einkum latínu og grísku, trúfræðigreinar, landafræði, sögu og stærðfræði, svo og móðurmálið og einhver nýmálanna. Í prengslunum hlutu pó fornmálin og trúfræði að eiga meginsess og einhverjar hinna greinanna að víkja. Skólasveinar voru 30-40, margir peirra fulltíða menn og dvöldust oft 5-6 ár í skólanum. Hver nemandi sat pá 2-3 ár í sama bekk og að hluta til með nýjum félögum á hverju ári en kennarar urðu að semja sig að miklum breytileika í undirbúningi nemendanna.

Enginn nemandi komst í skólann án meðmæla sem send voru biskupi en í flestum bréfanna var einnig sótt um ölmusu (skólastyrk) fyrir piltana vegna bágra aðstæðna. Par var líka sagt frá eðliskostum sveinanna og pví sem peir höfðu lært í heimaskólum. Oftast var mest skrifað um undirstöðu peirra í latínu en fyrir kom að ást á móðurmálinu var líka talin til góðs undirbúnings og mannkosta, sbr. eftirfarandi (Bps. 5b):

\section{Júní 1833:}

Úr umsókn E. H. Thorlacius um skólavist fyrir Pórarin Kristjánsson:

... giörir lángt framyfir alldur gódan íslendskan Stil, svosem hann unnir formerkjanliga sínu módurmáli, öllu paradlútandi Antiqviteti og historia Patria [svo]; er flestum norrænum Sögum velkuñigr, og les med eptirsókn allt sem par ad lútandi útkemur.

Kennarar í Bessastaðaskóla voru prír fyrstu árin en fjölgaði í fjóra haustið 1822 og urðu ekki fleiri. Yfirmaður skólans var nefndur lektor og kenndi trúfræðigreinar. Lektor fyrstu fimm árin var Steingrímur Jónsson, síðar biskup, en við tók Jón Jónsson guðfræðingur sem fylgdi skólanum til enda. Pekktustu kennarar skólans voru dr. Hallgrímur Scheving, dr. Sveinbjörn Egilsson og Björn Gunnlaugsson. Hallgrímur hóf kennslu 1810 og kenndi alla tíð latínu. Hann lauk prófi í latínu og grísku frá Hafnarháskóla og síðar doktorsprófi paðan. Sveinbjörn Egilsson kom í skólann 1819. Hann var guðfræðingur, fræðimaður og skáld og kenndi mest grísku og mannkynssögu. Björn Gunnlaugsson var stærðfræðingur og landmælingamaður og kenndi ýmsar greinar frá 1822. Allir voru peir við skólann uns hann var fluttur til Reykjavík- 
ur og pangað fylgdu peir honum (um Bessastaðaskóla sjá t.d. Aðalgeir Kristjánsson 2005:54-73 og Svavar Pór Guðmundsson 1997, einkum bls. 7-16).

\subsection{Fyrirmæli um Bessastaðaskóla}

Danska Skólastjórnarráðið, p.e. Den $\mathrm{kgl}$. Direction for Universitetet og de lærde Skoler, var sett á stofn 1805 (LS 6:764-765). Ráðið hafði yfirumsjón með allri starfsemi æðri skóla í Danaveldi og í pví sátu prír menn, p.e. fulltrúi konungs og tveir prófessorar við háskólann í Kaupmannahöfn. Ritari pess frá upphafi var Laurits Engelstoft (17741851), prófessor í sagnfræði. Hann varð assessor í ráđinu 1812 og sat í pví 1817-1832 og 1840-1848 en pá var pað lagt niður (Dansk Biografisk Leksikon 1979-1984, 4:195-196). Engelstoft var kunnugur mörgum íslenskum menntamönnum, átti við pá margvísleg bréfaskipti og var áhugasamur um íslensk skólamál (IB. $50 \mathrm{fol}$.). ${ }^{2}$

Árið 1805 bárust stiftamtmanni og biskupi kansellíbréf um stofnun „Interims-Skole“ (p.e. skóla til bráðabirgða) á Bessastöðum og fjölluðu pau mest um húsakost og fjármál skólans, launakjör kennara og ölmusur nemenda en lektor skólans skyldi árlega gefa Skólastjórnarráđinu skýrslu um ástand og starfsemi hans (LS 6:752-755). Af skýrslu lektors eftir fyrsta veturinn má ráða að ekki hafi pá verið skipt í bekki og óljóst er hvernig kennslan skiptist milli kennara (Sk. 1-41). Íslenska eða íslenskir stílar eru ekki nefndir meðal námsgreina en pýtt var úr latínu á íslensku eftir hádegi á laugardögum og líklegt er að pað hafi verið hugsað sem hluti latínukennslunnar. Næsta ár bárust áfram boð um umgjörð skólans en hinn 16. júní 1806 gaf ráðið ítarleg fyrirmæli (skrivelse) um starfsemi skólans (LS 7:41-75 og 76-80). Ekki verður annað séð en að pau hafi gilt alla tíð fyrir Bessastaðaskóla.

Í fyrirmælum ráðsins kom fram að hinn lærði skóli á Íslandi átti að starfa á sama grundvelli og skólarnir í Danmörku og Noregi eins og framast mætti verða. Par áttu að vera 30 nemendur í premur bekkjum og auk pess framhaldsdeild fyrir pá sem hugðust gerast prestar án háskólanáms í Kaupmannahöfn. ${ }^{3}$ Nemendur skyldu hafa nád 14 ára aldri, vera læsir og skrifandi og pekkja grunnatriði málfræði (p.e. latínu) og reiknings. Kennarar áttu að vera fjórir, hver að kenna sínar

2 Bréfasafnið var gjöf frá ekkju Engelstofts og í pví eru m.a. bréf frá Baldvini Einarssyni, Bjarna Thorarensen, Guttormi Pálssyni, Sveinbirni Egilssyni og Arnóri Árnasyni, flest um skólamál en nokkur um persónuleg málefni.

3 Eins og áđur var nefnt urðu bekkir aldrei fleiri en tveir í Bessastaðaskóla. 
greinar og notast við danskar og latneskar handbækur par til völ yrði á góðum pýðingum á íslensku. Рað var orðað pannig í fyrirmælunum: „Indtil de nödvendigste Elementair-Böger kunne udkomme i god islandsk Oversættelse hjælper enhver Lærer sig saa godt han kan med danske eller latinske Haandböger. “ Um kennslugreinarnar sagði enn fremur (LS 7:76-77):

Alle 3 Skoleklasser fælles Underviisnings-Gjenstande ere: det islandske, danske og latinske Sprog, Religion, Historie, Geographie, Arithmetik; i anden og tredje Klasse læres ogsaa det græske Sprog og Elementar-Geometrien og i den tredje endvidere en for den islandske Skole-Ungdom passende Encyclopædie af de almeennyttigste Kundskaber, samt, saavidt dertil er Tid, Begyndelsesgrundene i det hebraiske Sprog for dem, der agte at fortsætte det theologiske Studium ved Universitetet.

Ljóst er að dönsk skólayfirvöld ætluðust til að móðurmálið fengi sinn sess í skólanum og að námsgögn yrðu smám saman aðgengileg á íslensku. Рað virðist pví ekki hafa verið vilji peirra að skólamálið yrði danska pó að hún hlyti að henta best frekara námi í Danmörku. Kennarar skyldu mánaðarlega gefa biskupi og stiftamtmanni skýrslu um námsefni og kennslutilhögun en yfirvöldin senda ráðinu árlega afrit peirra. Stundatöflur skyldu gefnar út af ráðinu en frávik voru pó leyfð með rökstuðningi skólayfirvalda hér. Um bókasafn skólans var pað eitt sagt að ráðið mundi senda pví bækur árlega og par á meðal bækur til dreifingar meðal nemenda.

Viðauki um kennslufyrirkomulag í dönskum og norskum skólum mun hafa fylgt fyrirmælunum og var hverjum kennara Bessastaðaskóla sent eintak af pví til hliðsjónar (LS 7:43-69). Líklegt má telja að íslenskukennarar á fyrstu árum skólans hafi fylgt fyrirmælum um dönskukennsluna ytra par sem fram kom að æfa skyldi lestur, skrift og hugsun á „Modersmaalet" í fyrsta bekk en síðan málfræði, setningafræði og stafsetningu, svo og ritun stuttra ritgerða og sendibréfa, ýmist í tímum eða utan peirra. Kennara bar að leiðrétta stafsetningarog málfræðivillur í móðurmálinu og benda á æskilegt málsnið og orðalag. Hann átti að velja texta eftir pjóðskáldin, láta nemendur snúa ljóðum í óbundið mál og benda á sérkenni beggja tegunda en nemendur áttu líka að æfa sig í framsögn og pjálfa góðan málsmekk (LS 
7:57). ${ }^{4}$ Nákvæm fyrirmæli, er sérstaklega vörðuðu Bessastaðaskóla að pessu leyti,virðast ekki hafa verið send meðan hann starfaði.

Fyrirmælunum fylgdi handskrifuð stundatafla og par sést að vikustundirnar voru 42 í hvorum bekk en mesta vægið höfðu latína með 9 tíma og gríska með 6 tíma í hvorum bekk, svo og trúfræðigreinar með 6 tíma í neðri bekk en 12 tíma í peim efri. Í dönsku voru 5 tímar í neðri bekk og 3 tímar í peim efri. Auk pess voru á stundaskránni hebreska í efri bekk, landafræði og stærðfræði í neðri bekk og mannkynssaga sameiginlega í báđum bekkjum. Einni stund í viku var ráðstafað til framsagnar nemenda. Íslenskukennsla í töflunni bar heitið „Isl. Stilövelse“ og var sett í prjá tíma fyrir hvorn bekk. Kennari var Guttormur Pálsson, „Adj. G. Poulsen“ (Sk. 1-41 og Bps. 1a). Stundaskráin fyrir veturinn 1806-1807 var prentuð síðar í LS 7:74-75.

\section{3 Áherslan á móðurmálskennslu}

Varðveist hafa annálar Kaupmannahafnarháskóla og lærðu skólanna 1806-1813 en Laurits Engelstoft var ritstjóri peirra (Laurits Engelstoft (ritstj.) 1806-1813). Skýrslurnar fjalla fræðilega um skólamál en mest um háskólann, fjárhag skóla og skólafregnir frá öðrum löndum en pær bregða líka ljósi á reglur sem lærðu skólunum voru settar pó að í peim finnist engar heimildir um stundaskrár í Danmörku. Afar lítið er fjallað um íslenska skólann. Annálarnir bregða pó m.a. ljósi á pá staðreynd að móðurmálskennsla var talin nauðsynleg í æðri skólum Danmerkur og mikið um hana fjallað á pjóðræknislegum og uppeldislegum forsendum. Til prófs voru ritgerðarspurningar af siðferðislegum og pjóðernislegum toga en auk pess áttu nemendur að pýða af öðrum tungumálum á dönsku.

Í annálum Engelstofts er ritgerð um móðurmálskennslu eftir Jacob Rosted prófessor (1806:205-223). Par segir að kennsla í móðurmálinu sé afar mikilvægur hluti af fræðslu ungmenna í skólum pví að móðurmálið sé mælikvarði á göfgi pjóðar og framfarir. Ungmenni purfi að læra móðurmálið til að tjá göfugar hugsanir og tilfinningar. Móðurmálið geti ekki haldist óbreytt og pað purfi líka að nærast á fegurð annarra mála. Par séu klassísku málin gríska og latína leiðin til fullkomnunar. Með móðurmálskennslunni er sagt að ungmenni læri að tjá sig og tala rétt mál, málið sjálft verði par með sjálfstæðara og fastara fyrir.

4 Orðalagið er „anmærkes og rettes saavel Feilene imod Retskrivningen og Grammatiken, som i Fremstillingsmaade og Udtrykket". 
Allt bendir pví til að mennta- og uppeldisfrömuðurinn Engelstoft hafi alla tíð verið hliðhollur móðurmálskennslu í lærðu skólunum og að á peim grunni hafi íslenska strax fengið inni í stundaskrá Bessastaðaskóla prátt fyrir prengsli og kennaraskort. Greinin var talin upp fyrst í listanum yfir námsgreinar í öllum bekkjum skólans pó að fornmálin fengju flesta tímana. Skólamálaráđið taldi líka rétt að námsbækur væru sem flestar pýddar á íslensku eins og áður er getið.

\section{3 Íslenskukennsla í Bessastaðaskóla}

\section{1 Íslenskukennararnir}

Íslenskukennarar við Bessastaðaskóla voru fimm í rúmlega 40 ára sögu hans, p.e.:

Guttormur Pálsson, 1806-1807, ${ }^{5}$

Jón Jónsson (jr), 1807-1816,

Árni Helgason, 1816-1819,

Sveinbjörn Egilsson, 1819-1822, og

Björn Gunnlaugsson, 1822-1846.

Guttormur Pálsson (1775-1860) var kennari við Hólavallarskóla síðustu ár hans og jafnframt vararektor uns skólastarfi par var hætt $1804 .{ }^{6}$ Veturinn 1806-1807 var hann kennari í íslensku, grísku, sagnfræði og landafræði í Bessastaðaskóla. Eftir tveggja ára kennslu par fékk Guttormur prestakallið Hólma í Reyðarfirði og varð síðar lengi prestur í Vallanesi og prófastur í Suður-Múlasýslu. Áratugum saman hélt hann heimaskóla, kenndi unglingum kristindóm og undirbjó pilta til náms á Bessastöðum og í Reykjavík (Sigurður Gunnarsson 1864).

Áhugi Guttorms á íslenskri málfræði kemur vel fram í handritum sem honum eru eignuð en hann er talinn hafa skrifað eða látið skrifa málfræðirit með heitinu „Stuttur leidarvijsir fyrir Islendska i perra eigin Módurmaali“ (Guttormur Pálsson (?), án ártals). ${ }^{7}$ John R. Yelverton (1971:viii-xv og xviii) telur að málfræðin hafi verið ætluð nemendum Guttorms og ritun hennar hugsanlega hafin á Bessastaða-

5 Sem áður sagði virðist íslenska ekki hafa verið kennd sem námsgrein fyrsta vetur skólans.

6 Skólinn hefur ýmist verið nefndur Hólavallarskóli eða Hólavallaskóli.

7 Handrit málfræðinnar, Lbs. 1238 8vo, er merkt sem eign Jóns Porkelssonar, rektors Reykjavíkurskóla. 
árum hans. Engin merki eru hins vegar um pað í skjölum um skólastarf á Bessastöðum að petta rit hafi verið kennt par á tímum Guttorms eða síðar.

Jón Jónsson (1779-1817) stundaði málfræðinám við Kaupmannahafnarháskóla en lauk ekki prófi og hóf pá kennslu við Bessastaðaskóla. Jón kenndi sömu greinar og Guttormur en auk pess pýsku í efri bekk um tíma. Hann fórst í skipsskaða á leið til Danmerkur (Páll Eggert Ólason 1950:261).

Árni Helgason (1777-1869) lauk guðfræðiprófi frá háskólanum í Kaupmannahöfn 1807. Hann varð fyrst prestur á Reynivöllum í Kjós og síðar við Dómkirkjuna í Reykjavík 1814-1821. Lengst var hann prófastur í Kjalarnesprófastsdæmi og prestur á Görðum á Álftanesi en um tíma var hann einnig settur biskup. Árni var forseti Íslandsdeildar Bókmenntafélagsins 1816-1848 og ásamt embættisstörfum kenndi hann fjölda manna skólalærdóm til stúdentsprófs (Páll Eggert Ólason 1948:49-50). Árni kenndi grísku, sögu og landafræði auk íslensku stílanna.

Sveinbjörn Egilsson (1791-1852) varð stúdent úr heimaskóla Árna Helgasonar 1810, fór til náms í háskólanum í Kaupmannahöfn 1815 og lauk par guðfræðiprófi 1819. Sama haust gerðist hann kennari á Bessastöðum og kenndi par ætíð síðan en varð rektor hins nýja Reykjavíkurskóla 1846 uns hann lét af störfum í lok skólaárs 1851. Sveinbjörn var skáld og afkastamikill fræðimaður og pýðandi en um störf hans hefur víða verið fjallað (sjá t.d. Einar Ól. Sveinsson 1942:116-122 og Jón Árnason 1952:1-46). Hann kenndi alla tío grísku og mannkynssögu en auk pess landafræði í nokkur ár og íslensku prjá vetur í upphafi starfs síns og tvo vetur í upphafi rektorstíðar sinnar. Grískukennsla Sveinbjarnar var punginn í starfi hans fyrir Bessastaðaskóla og oftast las hann Hómerskviður með nemendum. Allt petta pýddi hann á óbundið mál fyrir kennsluna og las nemendum fyrir en pýðing hans á „Odysseifs-drápu“ var prentuð í Boðsritum Bessastaðaskóla (Sveinbjörn Egilsson 1829-1840).

Sveinbjörn skrifaði mikið um íslenska málfræði en allt er pað aðeins varðveitt í samtíningi í handritum hans (Sveinbjörn Egilsson, án ártals). ${ }^{8}$ Par er fjallað um hljóðskipunarfræði málsins, hljóðvörp (hljóðstafaskipti), ýmsar breytingar á samhljóðaklösum, svo og beygingar nafnorða, lýsingarorða (sannkenninga), fornafna og sagna. Málfræði-

8 Handritin hafa safnmarkið Lbs. 456 4to. Kver I og VII eru heillegust pessara handrita. Lbs. 4564 to I ber heitið „Ágrip af íslenzkri málfræði: um hneigingar íslenzkra orða“ en Lbs. 456 4to VII fyrirsögnina "Um hneigingar íslenzkra orða“. 
handrit Sveinbjarnar voru efni doktorsritgerðar Christians A. Wolf en hann taldi pau skrifuð með fyrirmynd í ritum R.K. Rask frá 1818 og 1832. Wolf telur hugsanlegt að Sveinbjörn hafi ætlað skipulegri hluta skrifa sinna til kennslu en hin brotakenndari hafi verið fyrstu drög hans (Christian A. Wolf 1977:ix-xv og 214-220). Ekki er ljóst hvort hann studdist við pessi skrif sem kennsluefni í íslensku en pó verður pað að teljast líklegt. Af bréfaskriftum fyrrum lærisveina sést að peir vissu af peim og töldu miður að pau skiluðu sér ekki í útgáfu. Pannig sagði í bréfi Jónasar Hallgrímssonar sem hann skrifaði Konráði Gíslasyni frá Reykjavík í mars 1841 (Haukur Hannesson, Páll Valsson og Sveinn Yngvi Egilsson 1989:66):

Hvað líður pér og skólanum? Scheving karlinn práir pig íslenska málfræði vantar okkur umfram allt - Egilsen hefur einhvurn veginn ekki tök á að búa hana til. Félagið verður að láta prenta ef pú nennir að semja.

Björn Gunnlaugsson (1788-1876) varð stúdent úr heimaskóla hjá Geir biskupi Vídalín 1808 en fór nokkrum árum síðar utan til háskólanáms í stærðfræði og lauk par lærdómsprófi. Hann gerðist kennari við heimkomuna og kenndi alla tíð stærðfræði, landafræði, dönsku og íslensku við Bessastaðaskóla. Björn stundaði árum saman landmælingar á Íslandi og var uppdráttur hans af landinu gefinn út 1844. Hann skrifaði einnig um tímatal, stjörnufræði og heimspeki (Páll Eggert Ólason 1948:217-218).

\section{2 Íslenskukennsla í Bessastaðaskóla}

Um fyrsta vetur skólastarfsins á Bessastöðum 1805-1806 eru fáar heimildir eins og áður var vikið að enda höfðu pá engin fyrirmæli borist um stundaskrá eða fyrirkomulag kennslunnar. Skólaárið 18061807 kenndi Guttormur Pálsson aðjunkt grísku og íslensku í báðum bekkjum, sögu sameiginlega báðum bekkjum en landafræði aðeins í neðri bekk. Íslenskukennslan, p.e. „Isl. Stilövelse“, átti prjá tíma vikulega í hvorum bekk sem fyrr sagði. Kennarar skrifuðu frá upphafi pessa skólaárs mánaðarskýrslur á dönsku um skólastarfið og voru pær sendar biskupi og paðan til Skólastjórnarráđsins. Skýrslur Guttorms voru ítarlegar og bregða ljósi á íslenskukennsluna hjá honum pennan vetur og fer hér á eftir ágrip peirra (Bps. 1a).

Fyrsta mánuðinn las Guttormur nemendum í neðri bekk kafla úr 
Heimskringlu Snorra Sturlusonar á latínu og petta pýddu peir og skrifuðu á íslensku. ${ }^{9}$ Í næsta tíma var farið yfir stílana, annaðhvort pannig að kennari las réttan texta og nemendur lagfærðu hjá sér eða pá að kennari leiðrétti stílana og útskýrði athugasemdir. Að pessu loknu las kennarinn íslenskan texta Snorra í Heimskringlu og lét nemendur skrifa hann í bækur sínar sem fyrirmynd hins íslenska sögustíls. Í efri bekk var tveimur tímum varið vikulega í að pýða latneska og danska texta á íslensku en í priðja tímanum las kennarinn íslenskan texta „fullan af villum" og lét nemendur velta fyrir sér orðavali og stíl og var peim pá ætlað að lagfæra eða breyta eftir smekk. Kennari fór síðan yfir og vakti athygli nemenda á muninum á grófu máli og vönduðu máli, eða með orðum Guttorms: „herved sögt at giöre dem opmærksomme paa Forskællen imellem det platte og det værdige i Sproget". Pá benti hann peim á stílbrigði sem ekki væru við hæfi og önnur sem væru málinu eðlileg. Hann benti peim einnig á beygingarleg sérkenni íslenskunnar í pýðingum úr dönsku og latínu.

Síðar um haustið las kennari nemendum danska og latneska texta úr mannkynssögu og landafræðiritum og lét pá pýða eða endurrita efni peirra á íslensku. Pá var farið að lesa úr Paradísarmissi Miltons í pýðingu Jóns Porlákssonar á Bægisá en tvær fyrstu bækur verksins höfðu komið út á íslensku í Danmörku nokkrum árum fyrr á vegum Lærdómslistafélagsins (sbr. Pál Valsson 1996:231). Um pýðinguna notaði Guttormur lýsinguna „den Meesterlige Islandske Oversættelse af Miltons tabte Paradis" en nemendur spreyttu sig á að skrifa íslenskan texta í óbundnu máli úr pýðingunni. Texta nemenda leiðrétti kennari með peim og leitaðist við að kenna peim muninn á bundnu og óbundnu máli og sýna fegurð ljóðsins. Guttormur las peim einnig íslenskan texta Snorra Sturlusonar og texta úr ritum Lærdómslistafélagsins sem var pýðing Sveins Pálssonar læknis á ritgerð um náttúrufræði (Sveinn Pálsson (pýð.) 1789:175-264). Loks setti hann peim fyrir ritgerðarefni í íslensku er byggðist á grískum goðsögnum par sem nemendur áttu að greina orsakir og afleiðingar atburða. Nemendur skiluðu pessu með góðum vitnisburði. Í jólaleyfinu fengu peir sem styst voru komnir í námi pað verkefni að pýða kafla úr ritum Ciceros á íslensku en peir sem betur voru settir áttu að skrifa ritgerð um fagurbókmenntir í heiðnum sið. Pýðing Paradísarmissis

9 Bókin var að líkindum sú útgáfa er fyrst kom út 1777 par sem íslenskur texti, danskur og latneskur birtust hlið við hlið. Bókin hét: Heimskringla edr Noregs konungasögor laf Snorra Sturlusyni = Snorre Sturlesons Norske Kongers Historie = Historia regum Norvegicorum. 
var áfram lesin og nemendur skrifuðu texta ritsins í óbundnu máli en kennarinn fjallaði um fegurð textans og sérstök atriði í íslenskri ljóðlist er vörðuðu málfar, stafsetningu, rím og höfuðstafi sem hann sagði vera sérstaka og aðeins til í íslensku. Um pað fórust honum svo orð í skýrslu sinni til yfirvalda (Bps. 1a):

Den $3^{\text {ie }}$ time er bleven continueret med at forandre Præst Thorlaksens Isl. Oversættelse af Miltons tabte Paradiis i prosaisk Stiil, med samme Anledning har jeg og sogt at viise dette Stykkes Skönheder, Forskiællen paa Poesie og Prosa samt det særegne i den iislandske Digtekunst i hensyn til Stavelse, Maal, Rim og de saakaldte Höfutstafir som ere den ganske egne.

Eftir áramótin las kennari áfram latneska og danska texta og lét pýða, m.a. goðsagnir úr lestrarbók Nissens. Nemendur glímdu áfram við texta Snorra Sturlusonar og áfram var haldið með stíla prisvar í viku og bætt við lestri úr sögubók Mallings sem nemendur endursögðu á íslensku og færðu í stílabækur. Kennarinn leiðrétti síðan og loks skrifuðu nemendur útgáfu kennarans í bækur sínar. Á vormánuðum var aðeins sagt að starfið hefði verið svipað og áður og á prófi fengu nemendur ýmist "meget godt", "godt", ,temmel. godt" eða „maadelig“ í íslenskum stíl (Bps. 1a og Sk. 2-8). Guttormur hætti kennslu petta vor enda búinn að fá prestsembætti á Hólmum í Reyðarfirði.

Skýrslur Jóns Jónssonar (Bps. 1a) fjölluðu ætíð fremur stuttlega um íslenskutímana en hann fylgdi dæmi Guttorms í upphafi og las báđum bekkjum fyrir kafla úr Heimskringlu á latínu og lét pýða á íslensku. Stílar voru leiðréttir og nemendum bent á villur og í hverju pær lægju og stundum áttu peir sjálfir að finna betri pýðingu og málsnið. Jón las neðribekkingum einnig fyrir úr Konungsskuggsjá á latínu og ritum Liviusar og áttu peir að pýða á íslensku en fyrst purfti hann pó að snara efninu á dönsku. Jón tók fram að nemendur í efri bekk hefðu gott vald á íslensku máli en peir virðast fljótt hafa orðið leiðir á stílunum svo að kennari hóf að kenna landafræði í nokkrum íslenskutímum. Pessu gerði hann grein fyrir í skýrslunni, taldi að nemendur hefðu mikla pörf fyrir landafræði sem ekki var kennd í efri bekk og kvaðst vonast til að Skólastjórnarráðið tæki pessu ekki illa. Í desemberskýrslunni 1807 gat hann pess að í efri bekk væru nemendur allir fullorðnir menn með góða færni í móðurmálinu og að 
meðal peirra hefði komið fram eindregin ósk um að læra pýsku í stað íslensku. Lektor skrifaði stiftsyfirvöldum bréf um petta en Jón hóf pýskukennslu pegar í stað. Í bréfi lektors voru röksemdir kennarans raktar og nefnt að Skólastjórnarráðið leyfði breytingar á stundaskrá. ${ }^{10}$

Næstu vetur var íslenska aðeins kennd í neðri bekk með pýðingum úr Konungsskuggsjá. Kennari leiðrétti texta og las peim loks hinn upprunalega íslenska texta sem peir skrifuðu niður til hliðsjónar. Nemendur skrifuðu líka stuttar ritgerðir um tiltekið efni en kennari las yfir og vakti athygli nemenda á villum í málfari og efni. Jón orðaði pað svo í skýrslu sinni: „derpaa har ieg giennemlæst deres Udarbeidelse, og giört dem opmærksomme paa de saavel formale som materielle feil". Stundum var lesið úr danskri sögubók en nemendur pýddu á íslensku. Í undirbúningi prófa voru íslenskutímarnir notaðir í upprifjun annarra námsgreina (Bps. 1b). Pýskukennslan lagðist af tveimur árum síðar og var pá aftur farið að skrifa íslenska stíla í efri bekk. Til er stundatafla skólans veturinn 1810-1811 og samkvæmt henni var íslenskur stíll kenndur í báđum bekkjum prisvar í viku (Bps. 2a). Stundum fengu nemendur ritgerðarefni (et kort Thema), t.d. um skemmtanir norrænna fornsagnapersóna sem peir skrifuðu um á íslensku en kennari benti peim síðan á málfars- og efnisvillur: „Disse have ieg siden kritiseret og rettet, saavel i henseende til materiale og form som sprogfeilene." Haustið 1814 fóru efribekkingar fram á að fá að læra landafræði í stað íslensku og veitti biskup sampykki fyrir pví pannig að næstu árin var íslenska aftur aðeins kennd í neðri bekk en allir nemendur tóku pó áfram vorpróf í íslenskum stíl (Bps. 2a).

Haustið 1816 tók Árni Helgason dómkirkjuprestur við íslenskukennslunni og kenndi í prjú ár. Hann skrifaði ætíð mjög stuttar skýrslur og um íslenskuna sagði hann venjulega: „Islandske Stilövelser haldtes 3 Timer ugentlig í hver klasse og Examinatoria í hver uge“ (Bps. 2a). Í skýrslu lektors í skólabyrjun 1818 kemur fram að nemendur hafi æft sig í að skrifa latneska og íslenska stíla áður en eiginlegt skólastarf hófst og í skýrslu sr. Árna að vikulega hafi nemendur pýtt úr latínu á íslensku og hafi svo fengið leiðbeiningar í pví sem aflaga fór í íslenskum beygingum og orðavali: „... bleve Disciplene giort opmærksomme paa Feil i Oversættelsen som i det Islandske Sprogs vendinger og valg af Ord“ (Bps. 2b). Skýrslur um skólastarfið urðu

10 Bréf dagsett 30. nóv. 1807. Bréfið endar pannig: „,... at Stiftsövrigheden behageligst ville tillade at fornemte Islandske Stilövelser 3 gange om ugen for II ${ }^{\text {den }}$ Classe maatte forandres til det tijske Sprogs Læsning“. 
smám saman strjálli og frá 1819 skrifaði hver kennari aðeins árlega skýrslu til biskups (Bps. 2b).

Sveinbjörn Egilsson kom til starfa í Bessastaðaskóla haustið 1819 og kenndi pá grísku, sögu, landafræði og íslensku. Í skýrslu hans fyrsta skólaárið var mest fjallað um grískukennsluna en um íslenskuna sagði hann: „For begge Klasser holdtes skriftlige Øvelser i Modersmaalet i de bestemte Tider." Vorið 1821 sagðist Sveinbjörn hafa látið nemendur í öðrum bekk æfa sig í móðurmálinu með pýðingum úr latínu, dönsku og léttum pýskum textum en í fyrsta bekk úr léttum dönskum og latneskum textum. Vorið 1822 sagðist hann hafa haft skriflegar æfingar í móðurmálinu daglega ýmist í efri eða neðri bekk og haft próf í lesnu efni en ekki er pess getið hvaða efni pað var. Kennt var prjá tíma í viku í hvorum bekk og próf haldin í báðum bekkjum að vorlagi (Bps. $2 \mathrm{~b}$ og 3a).

Sumarið 1822 var farið að huga að breytingum á stundaskrá og kennarar settu upp töflur sem miðuðust annars vegar við tvo bekki og hins vegar fjölgun í prjá bekki en kennurum fjölgaði í fjóra með komu Björns Gunnlaugssonar stærðfræðings. Vafalítið voru pessar breytingar hugsaðar með fyrirmæli Skólastjórnarráðsins í huga, hag skólapilta og kennslu greina sem höfðu orðið út undan fram að pessu, einkum stærðfræði sem ekkert hafði verið kennd í efri bekk. Niðurstaðan varð pó sú að engar breytingar voru gerðar á bekkjaskipan enda hvergi pláss í húsinu og úr varð að haustið 1822 fækkaði íslenskutímum í neðri bekk í tvo á viku en engin íslenskukennsla var lengur fyrir efri bekk. Neðanmáls við stundaskrá pennan vetur, sem send var biskupi, er textinn: „Anmærkning. For Mathematikens Skyld er islandsk Stiil udeladt af 2den Klasse“ (Bps. 3a og Sk. 3-26). Löngu síðar fjallaði lektor skólans um pessa breytingu í yfirlitsskýrslu um starfsemi skólans og segir að pegar mælingarfræðum var bætt við og reikningslist kennd meira en áður hafi orðið að „,kippa burtu íslendskum stíl fyrir efribekkínga úr Lestrar-töblunni, sem var missir i“ (Jón Jónsson 1841:14-15). Í próftöflum frá árunum eftir að íslenskur stíll lagðist af í efri bekk kemur fram að nemendur í lokaprófum (dimittendi) tóku ávallt próf í íslenskum stíl svo og neðribekkingar.

Björn Gunnlaugsson varð kennari í Bessastaðaskóla árið 1822 og tók við kennslu í íslenskum stíl sama haust en næstu 24 árin var hann eini íslenskukennari skólans. Ekki virðist Björn hafa lært málfræði né pekkt fornbókmenntir sérstaklega. Nokkuð ljóst er að íslenskan „dæmdist á hann" par sem aðrir kennarar höfðu mikla kennsluskyldu í fornmálunum og trúfræðilegum greinum. Stundaskráin pennan 
fyrsta vetur Björns sýnir að Sveinbjörn Egilsson kenndi pá vikulega 12 tíma í grísku, 2 í landafræði og 5 í sögu, Hallgrímur Scheving kenndi 12 tíma í latínu og 7 tíma í latneskum stíl, Jón Jónsson lektor kenndi 12 tíma trúfræði, 2 tíma hebresku, 4 tíma skýringar Nýja testamentisins og 1 tíma danskan stíl, en Björn Gunnlaugsson kenndi 9 tíma reikning, 3 tíma dönsku og aðra 3 danskan stíl en 2 tíma í íslenskum stíl í neðri bekk eingöngu. Vegna plássleysis gátu aðeins tveir kennarar verið í bekkjum í einu en 36 nemendur voru í skólanum (Bps. 3a).

Í fyrstu ársskýrslu Björns sagðist hann hafa látið nemendur skrifa danska stíla með pýðingum úr íslenskum texta Egils sögu en íslenskukennslan fólst einnig í pýðingum úr dönskum textum pessa tvo tíma vikulega í neðri bekk. Ekki er peirra getið neitt nánar. Næstu vetur voru tímarnir í íslenskum stíl fólgnir í að pýða latneska og danska texta um sögu Danmerkur og léttan texta eftir Cicero. Björn kenndi einnig latneskan stíl í neðri bekk og notaði til pess íslenskar bækur, t.d. Snorra-Eddu, en piltar pýddu einnig úr Ólafs sögu Tryggvasonar af íslensku á latínu og eftir leiðréttingar las hann peim fyrir latneska pýðingu Sveinbjarnar Egilssonar. ${ }^{11}$ Í dönskutímum lét hann nemendur lesa danska pýðingu próf. Rafns á Ólafs sögu Tryggvasonar og lét pá finna fornleg og íslensk áhrif í danska textanum (Bps. 3a, Sk. 5-1, 5-15 og 6-1).

Haustið 1829 bætti Björn við frumlegu efni í íslenskukennslunni og lét nemendur pýða úr Lærebog i Svömmekonsten eftir Gutsmuths en næstu tvö árin las hann nemendum fyrir úr sögu Danmerkur, Noregs og Holstens (Bps. 4b og Sk. 6-9). Næstu vetur voru skýrslur Björns enn stuttar en oft var efni íslensku stílanna tekið úr bók eftir Cornelius Nepos á pessum árum (Bps. 5a, 6a og Sk. 8-17).

Vorið 1835 var Björn enn að leiðrétta 18 íslenska stíla, 18 danska og 6 latneska tvisvar í viku í neðri bekk. Næstu vetur var pýtt úr danskri lestrarbók Rahbeks, mannkynssögu Kofods og verkum Sesars í íslenskum stíl en í dönskum stílum notaði Björn Fjölni og Sunnanpóstinn til pýðinga (Bps. 6a, 6b, 7a, 7b). Pegar hér var komið sögu var íslenskan kennd í fyrsta tíma á priðjudögum og fimmtudögum en fram að pví höfðu latína og gríska ávallt átt fyrstu tvo tímana (Bps. 6a). Um petta leyti hættu einstakir kennarar að gefa skýrslu til stiftsyfirvalda og var pað pá á hendi lektors sem í fyrstu skrifaði skýrslur á dönsku

11 Hér er átt við útgáfu á Fornmanna sögum á vegum Fornfræðafélagsins í ritröðinni Scripta historica Islandorum, de rebus gestis veterum borealium, í pýðingu Sveinbjarnar Egilssonar. Ólafs saga Tryggvasonar á latínu kom út í premur bindum 1828-1829 og mun hér átt við pá útgáfu. 
en síðar íslensku og hétu pær pá „Uppteiknun“ en hver kennari skilaði lýsingu á námsefni sínu og kennslutilhögun til lektors (Bps. 7b, 8a, 8b). Um íslenskukennslu Björns segir að hann hafi lagfært stíla alls bekkjarins en ekki er getið um efni peirra né kennsluna að öðru leyti. Skýrslur frá pessum tíma sýna að inntökupróf voru haldin m.a. í íslenskum stíl (Bps. 8a).

Frá skólaárinu 1840-1841 voru skýrslur Bessastaðaskóla prentaðar og fjölluðu m.a. um skólahald og útgáfustarfsemi, kennslustarfið og frammistöðu nemenda með vitnisburði um brautskráða nemendur í hverri grein. Lektor var ábyrgðarmaður og fram kemur að árið 1839 hafi verið send boð frá Skólastjórnarráðinu pess efnis að hver skólameistari skyldi framvegis láta prenta skýrslu um skólastarfið. Boðin bárust pó ekki fyrr en með vorskipum 1840 og enn tafðist útgáfan pví að ekki var ljóst hvort skýrslan ætti að vera á íslensku eða dönsku. Рað varð svo úr að skýrslan skyldi rituð á íslensku. Petta sagði lektor útskýra „hvarfyrir eg rita skírslu mína á íslendsku, sem mér hvert sem er sýnist, eins og Stiptsyfirvöldunum og svo hefir sýnst, vidurkvæmilegast; pví mest er pað umvardandi að íslendskir sjálfir fái elsku til skóla vors" (Jón Jónsson 1841:10).

Björn Gunnlaugsson fjallaði af nokkurri nákvæmni um kennslu í landafræði, reikningsfræði og dönsku pessi árin. Skýrslan um dönskuna lýsir pví m.a. hve málakennslan var í raun pverfagleg í skólanum en um petta sagði lektorinn (Jón Jónsson 1841:23):

Fyrst lætur hann lærisveinana lesa dönskuna, sídan snúa henni á íslendsku, og undireins géfur hann peim íslendsk ord yfir dönsku ordin, par sem lærisveinana vantar pau, gétur og um mismunandi eiginleika dönskunnar og íslendskunnar.

Um íslenskukennsluna sagði Björn yfirleitt: „Loksins hefi eg lagfært stíla pá ena sömu, og uppá sama máta sem híngad til“ (Jón Jónsson 1843:14).

Sumarið 1846 var Bessastaðaskóla slitið í síðasta sinn. Ljóst var að Björn Gunnlaugsson fengi aukna kennslu í sérgreinum sínum í nýja skólanum í Reykjavík og í bréfi til Sveinbjarnar Egilssonar, nýskipaðs rektors, 16. sept. 1846, baðst hann undan frekari kennslu í tungumálum og landafræði með pessum orðum (Sk. 12-1):

Jeg önskede helst at være fri for alle Stile, dansk læsning og Geographi, thi der er utallig mange, som gjöre dette bedre 
end jeg. Derimod kunde jeg tage mere af det Mathematiske, dersom Undervisningen i dette fag blev udvidet.

\subsection{Boðsritin og bókakostur nemenda og skólans}

Boðsrit Bessastaðaskóla voru gefin út í tilefni skólahátíðar á fæðingardegi konungs á árunum 1828-1840 en í tilefni vorprófa frá 1841. Boðsritin voru á íslensku en í peim birtu kennarar skólans niðurstöður rannsókna sinna sem ekki höfðu áður verið prentaðar. Meðal efnis voru pýðingar öndvegisrita, uppskriftir og greiningar fornkvæða, heimspekilegar ritgerðir, pjóðlegur fróðleikur og leiðarvísar um stjörnufræði og gang himintungla. Atkvæðamestur í ritstörfunum var Sveinbjörn Egilsson; pýðing hans á Ódysseifskviðu í óbundnu máli kom út á tólf árum en auk pess birti hann allmörg trúarleg fornkvæði í Boðsritunum (Sveinbjörn Egilsson 1829-1840). Pýðing Ódysseifskviðu varð til í grískukennslu Sveinbjarnar eins og áđur er getið en líklegt er að nemendur hafi eignast ritin eins og aðrir peir sem tengdust skólanum. Annað efni á íslensku virðast nemendur vart hafa fengið frá skólanum.

Af skýrslum kennara má ráða að í íslenskutímum hafi peir ávallt lesið fyrir texta á dönsku eða latínu til pýðingar á íslensku eða sett nemendum fyrir ritgerðarefni í tímum. Hvergi er pess getið að piltum hafi verið ætlað að lesa íslenskan texta utan kennslustunda og óvíst að peir hafi átt nokkra pá bók eða rit á íslensku sem pó var nefnd sem kennsluefni í skýrslunum. Bókakostur skólans sjálfs var einnig afar fátæklegur af öðru en pví sem Skólastjórnarráðið sendi honum árlega en рað voru mest boðsrit annarra skóla og kennslubækur til sölu í skólanum. Lengi var pað hlutverk Sveinbjarnar Egilssonar að hafa umsjón með pöntun og sölu bókanna en skrár sýna að mest voru petta trúfræðirit, latneskar, danskar og grískar málfræðibækur, orðabækur og sögubækur, landabréfabækur og kennsluefni í stærðfræði (Sk. 6-10 og Bps. 5b).

Í bókasafninu um 1830 voru örfáar íslenskar bækur skráđar og taldar gamlar eða ónýtar, svo sem Rímbegla, Landnáma, Hungurvaka og Sæmundar-Edda en lítið blað frá 1832 sýnir bó reikning fyrir að binda inn nokkrar bækur fyrir skólasafnið, p.e. Njáls sögu, Eyrbyggju, Hervarar sögu og Kristni sögu (Bps. 5a). Nokkru síðar er svo getið rita Lærdómslistafélagsins, Passíusálmanna frá 1800 og 1820 og sálmabókar frá Leirárgörðum 1801 (Sk. 5-10 og 7-4). Pað var svo vart 
fyrr en við flutning skólans til Reykjavíkur að hann tók að eignast myndarlegt safn íslenskra bóka og er skrá Jóns Árnasonar (1862) um bókakost skólans merk heimild um skólasafnið.

\section{Nám og skólavist Bessastaðasveina}

\subsection{Skrif skólapilta}

Oft var mikið mannval meðal Bessastaðasveina og pekkt er að í skólanum kynntust peir fjórir skólapiltar sem síðar hófu útgáfu tímaritsins Fjölnis, peir Jónas Hallgrímsson, Konrád Gíslason, Tómas Sæmundsson og Brynjólfur Pétursson, en ritinu hefur verið lýst sem „merkasta riti í sögu íslenskrar málhreinsunar" (Kjartan G. Ottósson 1990:66). Verður pó að telja óvíst að íslensku stílarnir hafi haft mikil áhrif einir og sér á málfar og málrækt peirra eða annarra skólapilta og miklu fremur að lærifeðurnir hafi skapað sérstakt málfarslegt umhverfi og skólaanda sem um leið varð kveikjan að örri próun málsins um miðbik 19. aldar. Um pað vitna líka æviminningar annarra skólapilta par sem vikið var að kennslunni og fyrir kemur að óbeint er vísað til hennar, t.d. í tímaritinu Norðurfara, sem peir Gísli Brynjúlfsson og Jón Pórðarson (Jón Thoroddsen) gáfu út 1848-1849 en Jón varð stúdent 1840 (Páll Eggert Ólason 1950:291) og Gísli 1845 (Páll Eggert Ólason 1949:45). Í formála fyrri árgangs ritsins segir m.a. (bls. vi-vii):

Hvað rithættinum viðvíkur, pá hefur oss aldrei verið kennd nein rjettritan á íslenzku í skóla, en vjer höfum að pví leiti sem vjer höfum getað viljað fylgja rjettritan Hr. Konráðs Gíslasonar, pví oss finnst hún sjálfri sjer sampykkust ...

Hér á eftir verður fjallað lítillega um skrif priggja skólapilta, peirra Jónasar Hallgrímssonar, Páls Melsteð og Árna Thorsteinssonar til að bregða týru á nám peirra og skólavistina.

\subsection{Jónas Hallgrímsson}

Jónas Hallgrímsson komst í Bessastaðaskóla haustið 1823, sat par sex vetur og útskrifaðist vorið 1829. Til eru ýmsar heimildir frá pessum árum hans í skólanum en rit hans sjálfs sýna málfar og rithátt pessa tíma. Á pessum árum voru 36-41 nemandi í skólanum (Sk. 7-3) en 
skólaárið 1826-1827 voru „Fjölnismenn“ allir í skólanum. Fyrstur útskrifaðist Tómas og hlaut m.a. einkunnina "meget got“ í íslenskum stíl á burtfararprófi í maí 1827. Vorið 1828 útskrifaðist Brynjólfur með "got“ í íslenskum stíl og Jónas með sama vitnisburði ári síðar. Konráð kom í skólann haustið 1826 en útskrifaðist vorið 1831 með besta vitnisburði og einkunnina „meget got“ í íslensku (Sk. 7-3).

Fræðimenn hafa bent á að í skólanum hafi málfar Jónasar bæði í lausamáli og kvæðum mótast og hann notið par áhrifa Sveinbjarnar Egilssonar (Kjartan G. Ottósson 1990:67). Aðrir höfundar hafa kveðið svo fast að orði að segja skáldskap Jónasar beinlínis fram kominn vegna áhrifa Sveinbjarnar og Hallgríms Scheving pví að peir hafi haldið uppi „heiðri málsins“ og verið grundvöllur peirrar endurreisnar málsins sem fram kom síðar í Fjölni í skrifum Jónasar og Konráđs Gíslasonar (Benedikt Gröndal 1923:96).

Margt hefur varðveist af skrifum Jónasar frá skólaárum hans og par ber hæst æskuljóðin sem hann byrjaði að safna saman í kver. Stundum fannst honum vistin daufleg í skólanum en huggaði sig pá við lestur eddukvæða og erlendra skálda (Haukur Hannesson, Páll Valsson og Sveinn Yngvi Egilsson (ritstj.) 1989:5). Lausamálstextar Jónasar eru dæmi um málfar hans, stafsetningu og ýmis beygingarleg atriði málsins og hugsanlega eru peir einnig til marks um svipmót íslenskunnar hjá öðrum skólapiltum pessa tíma og hvernig peim var kennt að rita íslenskt mál.

Varðveist hefur örlítið handrit, p.e. nokkur blöð 8,2x5,3 cm, úr „skólablaði“ sem nefnt hefur verið Íris og mun Jónas hafa skrifað pað allt haustið 1826. Рað er dagsett „18 föstudægin̄ pan̄ $3^{\text {ia }}$ Novmb $26^{\prime \prime}$ og merkt no. 2 en önnur tölublöð virðast týnd. Í ritinu er fyrst kímnigrein um hebreskukennsluna en síðan prjár smágreinar og hin síðasta um dýravernd. Hún er pannig, skrifuð eins og Jónas stafsetti (KG 31.a.1.):

Dyranna Medhöndlan

Valla getum vér hrundid fra oss peim pánka ad Dyramordid í pad hærsta leifist pá naudsyn krefur, eñ aldrei til eintómrar skemtunar; valla gétum vér deifa hiá oss pá hugsión ad fyrri eñ kedjan pritur vid hastóli hins eilífa, hlióti eñ pá fynnast 1000 verur lifandi á baki hvura madurin stendur eins langt og Riúpan á baki veidi mansins.

Vei oss! ef pessir máttgari vildu fylgia pví dæmi ver géfūm peim.

(Fram haldid sidar.) 
30. maí 1829 hélt Jónas prófræðu sína í Bessastaðakirkju og lagði út af ritningartextanum í fyrsta Jóhannesarbréfi sem hann ritaði pannig: „Elskid ecki heimin̄, ecki heldur pá hluti sem í heiminum eru; ef nockur elskar heimiñ í hönum er ecki kiærleiki födursins." Ræðan var afar vönduð að uppbyggingu, upphafin að efni eins og tilefninu hæfði en pó jarðbundin. Hana er í heild sinni að finna í skjalasafni Konráđs Gíslasonar (KG 31.a.1). Ræðan hlýtur að teljast til heimilda um málviðmiðin í skólanum pegar mest var vandað til verka en Jónas var pó varla neinn meðalmaður hvað stíl og orðfæri varðaði. Hér verður að nægja að benda á nokkur atriði stafsetningar en margvísleg málfræðileg atriði pessa tíma má einnig greina í textanum (Alda B. Möller 2014:52-57 og 73-77).

Texti Jónasar hefur á sér nokkuð fornlegan blæ, einkum vegna notkunar á styttingarböndum yfir nefhljóðatáknum en oft er böndunum í raun ofaukið miðað við sígilda stafsetningu. Jónas notar ekki bókstafinn ð enda var táknið ekki endurvakið fyrr en nokkrum árum síðar. Bókstafurinn $z$ er heldur ekki notaður í textanum og nær hvergi er $j$ að finna, en $i$ skrifað pess í stað. Bókstafurinn y er notaður samkvæmt uppruna í ýmsum algengum orðum en handahófskennt pess utan. Jónas skrifar qv en ekki $k v$ og hann skrifar ætíð $c k$ í stað $k k$. Jónas hefur nær alltaf breitt sérhljóð/tvíhljóð á undan $n g$ og hann skrifar é og ie á eftir framgómmæltu $g$ og $k$ en ýmist é eða ie fyrir eldra é. Loks skrifar hann ei en ekki $e$ á undan gi og $g j$. Eftirfarandi eru tvö textabrot:

Vér meigum̄ ecki elska heimin̄. Orsökina leggur postulin̄ siálfur til: Hvör sem elskar heimin̄, seigir han̄, í hönum er ey kiærleiki födursins. Pad er ad skilia: hvör sem festir hiartad vid fallvaltan̄ heim, og hans giædi, hañ sínir par med ad han̄ ei elskar gúd, pvi hañ óhlídnast gúds vilia. Gúd vill nefnilega ad heimsins giædi skuli hressa og gledia oss, so oss aukist kraptar til ad gégna vorri köllun.

Sá sparar sier pvi mikla sorg og margañ söknud og qvída, sem numid hefur pá gullvægu kunst, ad geta verid án pess alls sem heimurin̄ megnar ad svifta mañ. Pegar heimsins blyda felur sig, og náttúruñar um̄brot skélfa man̄in̄, pegar hallæri eda stríd eda drepsóttir geisa ílöndunūm, og konúngarnir titra, pá er sá madur óhræddur, pvi hañ qvídir aungū̄ Iardneskū̄ missir, stödugur vid sitt skylduverk, bídur han̄ hvörs sem ad höndū̄ ber, og tekur ánægdur allskins skorti, ... 


\subsection{Páll Melsteð}

Páll Melsteð (1812-1910) kom í skólann haustið 1828 og lauk brottfararprófi 1834, m.a. með vitnisburðinum „meget got“ í íslenskum stíl (Bps. 6a). Endurminningar hans geyma lýsingu á náminu og skólalífinu pessa vetur (Páll Melsteð 1912:16-50).

Bóknám Páls byrjaði reyndar á pví að faðir hans lét hann skrifa upp stutta málfræði á íslensku, „líklega eftir Rasks bókum“, og lét hann læra. Páll nefnir íslenskukennslu Björns Gunnlaugssonar en fjallar ekkert um hana og sagði Björn ekki hafa verið eftirtektarsaman kennara. Um Hallgrím Scheving latínukennara segir Páll að í tímum hjá honum hafi vaknað hjá sér umhugsun um móðurmálið og löngun til að vanda orðavalið. Í efri bekk var Páll í dönsku hjá Sveinbirni Egilssyni en sagðist ætíð hafa lært íslensku í tímunum pví að hann var „meistari að pýða önnur mál á íslenzku“. Í sögukennslunni hjá Sveinbirni segir hann nokkuð af tímanum hafa farið í að snúa dönsku máli kennslubókarinnar á íslensku en af pví hafi hann lært íslensku en ekki sögu. Páll kvað kennarana fáar eða engar bækur hafa keypt og „menn lifðu á moði fyrri tíma“. Skólaveinar lifðu og hrærðust í sögnum um hetjuöld Grikkja og Rómverja og fornöld Norðurlanda. Peir lásu klassísk latnesk og grísk rit í tímunum en „Njálu, Grettlu og Eglu á svefnloftunum“. Pröngt og óhreinlegt var í skólanum en sveinarnir kunnu pó að skemmta sér, m.a. með glímum, tvísöng og flutningi leikrita.

\section{4 Árni Thorsteinsson}

Árni Thorsteinsson (1828-1907), síðar landfógeti, var íBessastaðaskóla 1844-1846 og síðan eitt ár í Reykjavíkurskóla. Hann skrifaði löngu síðar endurminningar sínar frá Bessastaðaskóla (Árni Thorsteinsson, án ártals, Minningar úr Bessastaðaskóla). ${ }^{12}$ Kennsluna og námsefnið taldi hann hafa verið orðið úrelt enda kennarar orðnir rosknir en peir nutu virðingar skólapilta vegna fræðimennsku sinnar. Hann lýsir mest peim áhrifum sem Sveinbjörn Egilsson hafði á nemendur og segir framfarir sem um pær mundir urðu í íslensku máli og bókmenntum hafa verið honum öðrum fremur að pakka og að hann hafi með málsnilld sinni haft mikil áhrif á pá. Hann hafi bæði byggt á samtímamálinu og tekið úr fornu máli pað sem best átti við. Hann segir enn fremur: „Engum var sem honum lagið með nýgjörfinga í málinu,

${ }_{12}$ Óprentuð ritgerð án safnmarks. 
og yndi var að heyra hann í kennslustundum vera að velta fyrir sér og lærisveinunum, hvörnig útlegging kæmi best heim við frummálið og pýðinguna.“ Árni nefnir einnig kennslu Hallgríms Scheving sem hann segir hafa verið stranga og fastmótaða en að honum hafi einnig verið mjög annt um að íslenskar pýðingar væru vel af hendi leystar.

Árni Thorsteinsson sagði skólapilta hafa verið afar iðna við „,dauðu málin“ og lásu pá pétt saman. Líkt og Páll Melsteð talaði hann um sóðaskap og sagði loftið í bekkjunum hafa verið ópolandi og „furða að eigi varð mein af“. Pessar hugleiðingar Árna, en jafnframt kvíði vegna flutninga frá Bessastöðum til Reykjavíkur, koma vel fram í sendibréfum hans, par sem segir m.a. (Árni Thorsteinsson, án ártals, Lbs. 2429 4to):

7. okt. 1845:

Nú held eg loksins að skólinn komist í Reikvik, qvíði eg fyrir pví að nokkru leiti. Húsakinnin verða að sönnu betri pví paug mega ekki lakari vera eñ paug eru hérna á Bessastöðum.

20. nóv. 1846:

Reykjavíkurbúar eru misjafnir menn, tilfin̄íngar peirra eru daufar eða engar í mörgum hlutum, svosem hvað pjóðerni Íslendínga snertir, málefni lands vors og málið okkar Íslendskuna meta peir lítils, alteins og pað sé gamall gripur ónítur og sem farið sé að falla á.

\section{Fyrstu reglugerðir um Reykjavíkurskóla}

\subsection{Bráðabirgðareglugerð 1846}

Sumarið 1845 birti Skólastjórnarráðið danska bráđabirgðaskipan fyrir lærða skóla í Danmörku. Sveinbjörn Egilsson, nýskipaður rektor Reykjavíkurskóla, var næsta vetur í Kaupmannahöfn og má af gögnum ráða að orðalag um námsefni í íslensku í hinum nýja skóla hafi verið sniðið að pví orðalagi sem gilti um dönskukennslu parlendis pví að í eintaki reglugerðarinnar er einfaldlega skrifað með hendi Sveinbjarnar orðið „,islandsk“ í stað „dansk“ par sem við á (Sk. 13-1). Önnur skrif Sveinbjarnar frá sama tíma styðja petta pví að uppkast 
hans, líklega skrifað í Kaupmannahöfn pennan vetur, sýnir að hann gerði ráð fyrir að málakennslan hérlendis viki frá dönsku reglunum og að tungumálin yrðu kennd pannig (Sk. 12-1):

Islandsk, ligesom Dansk efter Prov. Plan. 4,1 og 11,1,

Dansk ligesom Tydsk efter Prov. Plan. 4,2 og 11,2,

Tydsk ligesom Fransk efter Prov. Plan. 4,3 og 11,3.

Með pessari aðlögun fékk pví íslenska hliðstæða stöðu og danska móðurmálið í dönskum skólum en hérlendis varð danska fyrsta erlenda tungumálið og pýska annað í námskránni. Skólastjórnarráðið gaf út bráðabirgðareglugerð fyrir „den lærde Skole i Reykjavik“ sem tók gildi 1. okt. 1846 (LS 13 1866:435-463). ${ }^{13}$ Íslensk pýðing hennar birtist í Reykjavíkurpóstinum sama ár (1846: 1, 2, 3; 1847: 4, 5, 6). Skólinn skyldi undirbúa menn fyrir háskólanám en einnig fyrir nám í prestaskóla sem setja átti á laggirnar. Nemendur skyldu ekki koma eldri í skólann en sextán ára, kunna undirstöðuatriði í tilteknum greinum og vera fermdir, bólusettir og óspilltir. Engar sérstakar kröfur voru gerðar um kunnáttu í íslensku aðrar en pær að geta lesið hana og skrifað læsilega. Tekið var fram að íslenska og danska ættu að vera aðalkennslugreinar í neðri bekkjum skólans en í efri bekkjum var miðað við að fornmálin yrðu aðalgreinar. Um kennslu í íslensku sagði eftirfarandi (LS 13 1866:450-451):

Íslenzk túnga: Hana skal kenna í öllum bekkjum, en sá er tilgángur peirrar kennslu, í fyrsta lagi að kynna lærisveinum með pessari túngu hinar almennu hugmyndir málfræðinnar, í öðru lagi að kenna peim að rita móðurmál sitt samkvæmt rèttum reglum, óblandað og með góðum smekk, í priðja lagi að kynna peim bókmentasögu Íslands.

Pessi grein mun hafa verið samin eftir bráðabirgðareglum (Provisorisk Plan) frá 1844 um dönskukennslu í lærðum skólum í Danmörku og var sýnilega aðlöguð fyrir Ísland með sama hætti og áður var getið pví að í danska textanum var strikað yfir orðið „dansk“ og pess í stað skrifað orðið „islandsk" með hendi Sveinbjarnar, að pví er best verður séð (Sk. 13-1).

13 Reglugerðin nefnist á dönsku „Forelöbigt Reglement for den lærde Skole i Reykjavik, Khavn 30. Mai 1846“. Íslensk pýðing fylgir danska textanum og mun hún vera orðrétt úr Reykjavíkurpóstinum frá 1846-1847. 


\subsection{Reglugerðin 1850}

Reglugerð um kennsluna og lærdómsprófin í hinum lærða skóla í Reykjavík var gefin út fyrir Island 30. júlí 1850 (LS 14 1868:495-528). Pá hafði Skólastjórnarráðið verið lagt niður en skólamál færð til Kirkju- og skólamálaráðuneytis Danmerkur. Hlutverk skólans var nú orðið víðtækara en áđur pví að auk undirbúnings fyrir Prestaskólann og háskólanám skyldi hann „veita lærisveinum peim, sem honum eru á hendur faldir, pá tilsögn, er leiða megi til sannrar og röksamlegrar frummentunar“ (LS 14 1868:515). Íslensku urðu menn að geta lesið og ritað læsilega og "stórlýtalaust að rèttrituninni til“ pegar peir komu í skólann en í skólanum áttu nemendur að kynnast íslenskri tungu og bókmenntum hennar. Í reglugerðinni var pví auk pess lýst yfir að íslenska móðurmálið í íslenska skólanum skyldi vera jafnrétthátt móðurmálinu í dönsku skólunum - „Det islandske Modersmaal i den islandske Skole sættes jævnsides med Modersmaalet i de danske Skoler", og virðist pað hafa verið nýbreytni í reglugerðum. Inntaki kennslunnar var nú einnig lýst í fyrsta sinn í sögu skólanna (LS 14 1868:499,516):

Íslenzka. Hana skal kenna í öllum bekkjum; skal peirri kennslu svo haga, að piltum lærist að tala hana og rita hreint, rètt og lipurt; smásaman skal og kynna peim bókmentasögu Íslendínga og helztu rit. Í allri túngumálakennslu skal hafa íslenzkuna, til að gjöra piltum skýrar og skiljanlegar hinar almennu málfræðislegu hugmyndir, og pessar málfræðislegu hugmyndir á að heimfæra upp á íslenzkuna. Í efri bekkjunum eiga íslenzku ritgjörðirnar að vera pannig lagaðar, að piltar komist á pann rekspöl, að peir geti ritað um eitthvert efni af eigin rammleik.

Burtfararpróf skyldi halda í 13 námsgreinum, par á meðal íslensku, en prír prófdómarar lesa og dæma ritgerðirnar, p.e. tveir menn auk íslenskukennarans í 4. bekk. Próftilhögun er lýst svo (LS 14 1868:522):

Í íslenzku skal prófið að eins vera skriflegt, og vera í pví fólgið, аð lærisveinar riti um eitthvert efni, sem fyrir pá er lagt, og sem eigi er of vaxið peirri pekkíngu, sem ætlazt verður til af lærisveinum, eptir kennslu peirri, sem peir hafa notið; og pegar dæmt er um ritgjörðina skal eigi fara eptir pví, hversu 
mikla eða litla pekkíngu pilturinn sýnir í einhverri einstakri vísindagrein, heldur eptir pví, hversu ljós hugsun lærisveinsins er, og hversu vel, skýrt og hreint, hann getur orðfært hugsanir sínar.

Reglugerðin frá 1850 var í gildi fyrir Reykjavíkurskóla til 1877 er önnur leysti hana af hólmi en sú gilti til 1904. Í peim báđum var vægi íslensku í stundaskránni aukið (Heimir Porleifsson (ritstj.) 1975:112).

\section{6 Íslenskukennslan 1846-1848}

\section{1 Íslenskukennslan fyrsta veturinn í Reykjavík}

Úr Bessastaðaskóla fluttust 33 skólasveinar en 27 nýir nemendur fengu skólavist petta haust eftir inntökupróf í latínu, grísku, dönsku, sagnfræði, landafræði og reikningi. Nemum var síðan skipt í prjá bekki eftir frammistöðu (Sveinbjörn Egilsson 1847:1-7).

Vorið 1846 skipaði konungur Konráð Gíslason málfræðing kennara við skólann og var honum m.a. ætlað að kenna íslensku. Konráð hafði sótt um kennslustöðu á peirri forsendu að efla ætti kennslu í íslensku, dönsku og pýsku. Hvað móðurmálið snerti sagðist hann pekkja sögu pess og fræði betur en aðrir og taldi að málsaga ætti að vera hluti íslenskukennslunnar en kvað íslenskt mál samtímans sér einnig hugleikið og vísaði til vinnu sinnar við útgáfu Fjölnis sem hefði verið „,boðberi hreintungunnar og stílfegurðar og önnur rit ekki betur skrifuð á nútímamálinu“ (Aðalgeir Kristjánsson 2003:269-270). Konráð kom pó ekki til starfa, bæði af persónulegum ástæðum og einnig vegna pess að hann var pá kominn á pá skoðun að rannsóknum í norrænum fræðum væri varla hægt að sinna nema í Kaupmannahöfn (Aðalgeir Kristjánsson 2003:126). Sveinbjörn Egilsson rektor tók pá að sér íslenskukennsluna en fyrsta ár skólans var íslenskur stíll aðeins kenndur einn tíma í viku í hverjum bekk. Um námsefni í íslensku pennan vetur fórust honum svo orð (Sveinbjörn Egilsson 1847:8-10):

Í íslenzku: hèr hefir einúngis verið 1 stíll í viku í hverjum bekk. Stílsefnið í 1. bekk var tekið af „Malings store og gode Handlinger", og stundum valdar smásögur og ritlíngar úr pjóðblaði Dana (Folkebladet). Í 2. bekk var stílsefnið ýmist tekið úr dönsku eða latínu; í 3. bekk ýmist úr dönsku, latínu eða pýzku. 


\section{2 Íslenskir stílar Magnúsar Grímssonar 1846-1847}

Varðveist hafa íslenskir stílar Magnúsar Grímssonar (1825-1860), nemanda Sveinbjarnar pennan fyrsta vetur í Reykjavíkurskóla. Magnús var í Bessastaðaskóla frá 1842 og varð stúdent 1848 frá Reykjavíkurskóla. Hann gerðist prestur á Mosfelli en var einnig rithöfundur, leikskáld, pýðandi og blaðamaður á stuttum starfsferli sínum (Páll Eggert Ólason 1950:424). Merkast verka hans er söfnun íslenskra pjóðsagna með Jóni Árnasyni en peir kynntust í Bessastaðaskóla. Flestum sögunum safnaði Magnús sjálfur eða meðal skólapilta á Bessastöðum en pær fengu peir í sumarleyfum sínum um allt land (Magnús Grímsson 1926:3-27).

Bók Magnúsar með íslensku stílunum veturinn 1846-1847 hefur á titilsíðu textann: „Tilraunir Magnúsar Grímssonar til að rita íslenzka túngu, lagfærðar af herra Sveinbirni Egilssyni Doctor Theol, veturinn 1846 og 1847“ (Magnús Grímsson 1847). Textarnir eru úr sögum á latínu og dönsku, 100-150 orð hver, sem skrifaðir voru niður og síðan pýddir á íslensku. Íslenska textann lagfærði kennari hvað orðaval, orðaröð og stafsetningu varðar en slíkar athugasemdir voru fremur fátíðar. Nemandi skrifaði nokkrar fyrirspurnir til kennara sem leysti úr málinu en pað ber vott um að kennarinn hafi tekið stílinn með sér til yfirlestrar. ${ }^{14}$ Latnesku sögurnar fjölluðu um grískar fornhetjur. Hér er brot úr pýðingu Magnúsar á sögunni um Abdólónímus. Sveinbjörn skrifaði athugasemdir sínar ofan textans en hér eru pær sýndar með skáletri í sviga. Stakt tilbrigði Magnúsar sjálfs er sýnt án skáleturs í sviga eins og hann skrifaði pað.

Hinir úngu menn, sem (vèr) höfum áður um getið, fóru með konungleg klæði inn í garðinn, en pá vildi svo til, að Abdólónímus var að hreinsa hann og tína úr honum illgresi. Pegar peir voru búnir að heilsa honum sem konúngi, tók annar peirra svo til orða: petta klæði, sem pú sèr í höndum mínum, skaltu nú taka í staðinn fyrir óhreinu ræflana, sem pú ert núna í. Tak pèr konúnglegt hugarfar, og vertu svona sparsamur í tign peirri, er pèr nú veitist og pú ert maklegur. Og pegar pú ert seztur í konúngssætið, og orðinn einráður lífs og dauða manna pinna, skaltu varast að gleyma pessari

${ }_{14}$ Dæmi um petta er pegar Magnús spyr: „Er til nokkurt orð hjá okkur yfir Mumier?“ Sveinbjörn svarar: „P. Melsted bjó til orðið smyrðlíngar, eg veit ekkert betra." 
stöðu, sem pú tekur við völdunum í, og (peim) sem pú átt að pakka tign pína. Abdólónímus pótti sem sig væri að dreyma, og spurði hina úngu menn hvert peir væru með öllum mjalla (öllu viti), par sem peir göbbuðu sig svo ósvífnislega.

[Síðar] ... eg vildi eg gæti orðið eins ánægður með konúngdóminn, og eg var með fátæktina. Pessar höndur hafa fyrir mèr unnið (eða: pessar höndur hafa fullnægt pörfum mínum).

Í textabrotinu sést að Sveinbjörn leiðrétti ófullkomnar setningar og fyllti par í eyður og hann lagfærði óformlegt orðatiltæki. Hann gerði hins vegar engar athugasemdir við sagnbeyginguna sèr í stað sèrð í 2.p.et.nt.fh. sem er merki um eldri rithátt og hann merkti heldur ekki við fleirtölumyndina höndur sem mun hafa verið nokkuð algeng orðmynd á 19. öld, einkum í talmáli (Björn K. Pórólfsson 1925:112,87). Hvað stafsetningu varðar í stílunum hefur Magnúsi greinilega verið kennt að nota $z$ og $y$ eftir uppruna orða, breiður sérhljóði/tvíhljóði er skrifaður á undan $n g$, táknið è er ritað en ekki je en hins vegar er skrifað eg en ekki èg. Greinarmerkjasetning virðist líka vel mótuð með kommum á undan samtengingum í flestum tilvikum. Athugun á flestum stílum Magnúsar leiddi í ljós að Sveinbjörn gerði margvíslegar en pó hófsamlegar athugasemdir, hann leiðrétti alltaf $y$-villur og $z$-villur og stundum benti hann á fornar orðmyndir til fyrirmyndar (Alda B. Möller 2014:58-61).

\subsection{Stafsetningarreglur Sveinbjarnar Egilssonar}

Líklegt er að Sveinbjörn hafi notað málfræðihandrit sín við kennsluna pví að stafsetning Magnúsar og leiðréttingar Sveinbjarnar eru í góðu samræmi við pau (Sveinbjörn Egilsson, án ártals). ${ }^{15}$ Hér verður aðeins lýst tveimur reglum Sveinbjarnar, p.e. um notkun y og z. Sveinbjörn kallar stafina „samsetta málstafi“ og segir um pá:

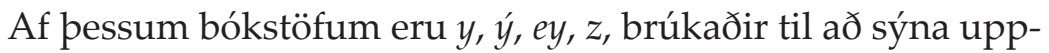
runa orðanna, pví að peim er kveðið sem að $i, i, e i, s ;$ hvar $y, y$, ey er brúkað, sèst af hljóðstafaskiptunum ( ), en $z$ brúkast fyrir $s$, pegar $t, d$ eða $\partial$ hefur verið slept á undan pví, t.d. veizla (f. veitsla), íslenzkur (f. íslendskur), gerzkur (f. gerðskur). ${ }^{16}$

15 Efni handritanna í Lbs. 456 4to var aldrei prentað eins og áður var vikið að.

16 Auði sviginn í 3. línu tilvitnunarinnar er pannig í handritinu. 
Áður hafði hann gert ítarlega grein fyrir hljóðvörpum, sem hann nefnir hljóðstafaskipti, með dæmum um fjölmörg orð sem rita skyldi með y vegna uppruna.

\section{4 Íslenskukennslan veturinn 1847-1848}

Veturinn 1847-1848 má segja að íslenska hafi loks orðið eiginleg námsgrein í skólastarfi hérlendis pví að pá hófst skipuleg kennsla í íslenskri málfræði og íslenskum bókmenntum. Pennan vetur var málfræðin kennd eftir formálanum í Islandsk Læsebog eftir Halldór Kr. Friðriksson sem pá var nýkomin út (Halldór Kr. Friðriksson 1846). Rektor kenndi íslensku tvo tíma vikulega í hvorum efri bekkjanna (3.a. og 3.b.) en Gísli Thorarensen var aðstoðarkennari hans og kenndi fjóra tíma vikulega í 1. og 2. bekk. Íslensku voru pví ætlaðar tólf vikustundir petta árið en meginbreytingin í stundaskránni var að öđru leyti sú að latínu- og grískukennsla var minnkuð mjög í neðri bekkjunum, dönskukennslan aukin par og farið að kenna frönsku og ensku í öðrum bekk. Í efri bekkjunum urðu minni breytingar og par var punginn áfram í latínu- og grískukennslunni (Sveinbjörn Egilsson 1848:8-9).

Gísli Thorarensen sagðist hafa látið nemendur í 1. bekk lesa Droplaugarsona sögu og lestrarbók Halldórs Kr. Friðrikssonar og hann kvaðst hafa látið læra „nafna og sagna breytíngar íslenzkrar túngu eptir ágripinu framan við lestrarbókina“. Í 2. bekk lásu menn Droplaugarsona sögu, Gylfaginningu í útgáfu Sveinbjarnar Egilssonar og fjórar fyrstu bækur Odysseifsdrápu í pýðingu hans. ${ }^{17}$ Goðafræði Norðurlanda var einnig kennd og samdar ritgerðir en vikulegir stílar teknir úr danskri lestrarbók. Með neðri bekkjunum báðum sagðist kennarinn líka hafa lesið öll kvæðin í ljóðabókum Bjarna Thorarensen og Jónasar Hallgrímssonar og pýtt með peim pað sem „púngskilið hefur pókt eða fornyrt" (Sveinbjörn Egilsson 1848:14-15).

Sveinbjörn Egilsson kenndi pennan vetur íslenska bókmenntasögu og ritgerð en um pað sagði hann í skýrslu sinni (Sveinbjörn Egilsson 1848:11):

17 Hér mun átt við útgáfu Ódysseifsdrápu í Boðsritum Bessastaðaskóla 1829-1840 og útgáfu á Gylfaginningu í Boðsriti Reykjavíkurskóla 1848 sem kann að hafa verið í handriti um petta leyti. 
(3.a) Tveimur stundum í viku var varið til að lesa fyrir ágrip af íslenskri bókmentasögu fram til 13. aldar, svo og stutt ágrip af hinum fornu bragarháttum, og munnlega hlaupið í gegnum háttatal Snorra, v. 1-30. Fám sinnum fyrirsett ritsefni á íslenzku.

(3.b) Tvisvar í viku reyndu lærisveinar til að semja ritgjörð yfir fyrir sett efni; ritsefnið var optast einhver almenn málsgrein, orðskviðir eða spakmæli, stundum biflíugreinir af gamla og nýa testamentinu.

Ritgerðarefni hjá Sveinbirni á lokaprófi vorið 1848 var: „Að útlista pessi orð lausnarans: Auðveldara er úlfaldanum að gánga gegnum nálaraugað en ríkum manni inn í Guðsríki." Ritgerðirnar voru 400700 orð í hátíðlegum stíl og væntanlega eftir uppkasti pví að mjög lítið er par um leiðréttingar. Ritgerðarefnin munu hafa verið lesin upp pví að ritháttur nemenda á fyrirsögninni er mismunandi. Ritgerðirnar hafa varðveist og fylgir hér lítið brot eftir Helga Hálfdanarson, síðar sálmaskáld og lektor Prestaskólans, sem sýnir hversu mjög var til vandað (MR Próf):

... pví pað hjarta, par sem svo margar íllar girndir lifa og próast, pað getur ekki verið musteri heilags anda; par sem drambsemi og úlfbúð, öfund og eigingirni og aðrir lestir, sem leidt geta af raungu áliti á auðnum og rángri notkun hans par sem petta ríkir, par getur ekki Guðs ríki verið, pví Guðs ríki er hverki matur né drykkur, auður né upphefð, heldur friður og fögnuður í heilögum anda.

\section{7 Íslenskukennslan hjá Halldóri Kr. Friðrikssyni frá 1848}

\subsection{Góð bót ráðin á íslenskukennslu}

Haustið 1848 kom Halldór Kristján Friðriksson til íslenskukennslu í skólanum en Sveinbjörn rektor lét svo um mælt í skólasetningarræðu sinni 1. okt. 1848 að Halldór hefði: „,ér í lagi lagt sig eptir pekkíngu á móðurmáli voru, og hyggjum vér gott til, að nú verði góð bót ráðin á pví, sem áður hefir heldur verið ábótavant í peirri grein“ (Skólaræður 
Sveinbjarnar Egilssonar 1968:76). Reyndist pað orð að sönnu pví að Halldór kenndi íslensku í nær hálfa öld með aðeins árs hléi, veturinn 1849-1850. ${ }^{18}$

Halldór Kr. Friðriksson (1819-1902) útskrifaðist úr Bessastaðaskóla 1842 og fór pá til Kaupmannahafnar til náms í guðfræði en lauk ekki embættisprófi. Par fékkst hann mjög við fornfræði og málfræði og vann nokkur ár að íslenskri orðabók Cleasby. Ytra starfaði hann einnig mikið með Fjölnismönnum og var ábyrgðarmaður tveggja síðustu árganga blaðsins. Auk kennslunnar sinnti hann margvíslegum öðrum embættisstörfum, var lengi alpingismaður og bæjarfulltrúi í Reykjavík, formaður landsbókasafnsnefndar og forseti Búnaðarfélags suðuramtsins, svo að fátt eitt sé nefnt (Jón Porkelsson 1947:415-435).

Halldór kenndi alla tíð íslensku og lengi pýsku, dönsku, ensku og landafræði. Í öllum kennslugreinum kostaði hann kapps um að hafa námsbækur á íslensku og ýmist pýddi pær eða samdi sjálfur. Hann pótti strangur kennari og sagt var að betra hefði verið að læra réttritun hans vel ef menn vildu ná árangri í íslenskum stíl og vissara var einnig að forðast dönskuslettur og önnur erlend áhrif í textum (Jón Porkelsson 1947:420, 434). Halldór er líklega pekktastur fyrir að koma á reglufestu í íslenskri réttritun sem hann kenndi alla tíð og nefnd hefur verið skólastafsetningin en með íslenskukennslu sinni og skrifum um málfar er hann talinn hafa haft meiri áhrif en flestir aðrir á íslenska málhreinsun allan síðari hluta 19. aldar (Kjartan G. Ottósson 1990:95-98).

Halldór tók saman efni í Islandsk Læsebog sem út kom 1846 og var hún ætluð Dönum sem áhuga höfðu á íslensku enda voru allmargir Danir hjá honum í íslenskunámi. Í formála bókarinnar var yfirlit um íslenska málfræði eftir Halldór og var pað notað við íslenskukennslu í Reykjavíkurskóla á fyrstu árum hans, eins og áour var getið, og er fyrsta bókin um íslenska málfræði sem vitað er að kennd hafi verið í skólum hérlendis. Síðar skrifaði Halldór bókina Íslenzkar rjettritunarreglur (1859) og loks samdi hann og gaf út bókina Íslenzk málmyndalýsing (1861). Allar voru pessar bækur notaðar til kennslu en mest og lengst hin síðasttalda.

18 Pann vetur sótti Halldór konuefni sitt til Danmerkur og vann að útgáfu íslenskra fornsagna í Kaupmannahöfn. 


\subsection{Kennsluefni og tilhögun náms fyrstu ár Halldórs Kr. Friðrikssonar}

Veturinn 1848-1849 kenndi Halldór íslenska málfræði og stíla í fjóra tíma vikulega í neðri bekkjunum. Í 3.a. og 3.b. voru hins vegar bókmenntir, norræn goðafræði og ritgjörð á stundaskránni en pó aðeins tvær stundir í viku í hvorum bekk. Í skólaskýrslum sagði m.a. um kennsluna í 2. bekk (Sveinbjörn Egilsson 1849:13):

1. hefur hann látið pilta læra ágripið af málmyndalýsíng íslenzkunnar, er stendur framan við lestrarbók hans; hefur hann og út skýrt og aukið petta ágrip í yfirheyrslunni svo, að piltar ekki að eins gætu fengið greinilegt yfirlit yfir myndir og beygíngar íslenzkunnar, eins og hún er nú, heldur gætu peir einnig borið pað saman við fornmálið.

2. lagfærði hann hjá peim tvo íslenzka stíla í viku; voru stílsefnin að mestu úr Udvalgte Fortællinger af J. P. Hebel, en nokkur úr Holst danske Læsebog.

Í 3.a. lásu menn norræna goðafræði og málfræði Halldórs en í 3.b. lét hann lesa Háttatal Snorra Sturlusonar, útskýrði vísurnar og vakti jafnframt athygli á „einkennum norrænna skáldskaparhátta, og myndum og beygíngum norrænunnar" (Sveinbjörn Egilsson 1849:14).

Veturinn 1850-1851 var málmyndalýsingin kennd í 1. bekk og nemendur lásu 9. árgang Fjölnis sem var minningarrit um Jónas Hallgrímsson. Í 2. bekk var málmyndalýsingin líka lesin ásamt Pórðar sögu hreðu sem Halldór hafði pá nýlega séð um útgáfu á en hana las hann pannig að hann hafði „stöðugt auga á málmyndalýsíngunni, og jafnframt mismuninum á máli voru núna og fornmáli voru“. Stílar voru svo gerðir tvisvar í viku - ýmist tímastílar eða heimastílar, og allt leiðrétti kennarinn. Í 3.a. voru aðeins stílar en í efsta bekk (3.b.) las kennarinn aftur Háttalykil Snorra Sturlusonar og lét skrifa ritgerð vikulega um ýmis efni, ýmist í tímum eða utan peirra (Sveinbjörn Egilsson 1851:13-14).

Til eru svonefndar lestrarbækur nemenda frá pessum árum, og reyndar alveg til aldamótanna 1900, en í pær skiptust nemendur á að skrá námsefnið sem farið var yfir í hverju fagi. Lesefni fyrsta bekkjar veturinn 1851-1852 er dæmi um slíka skrásetningu (MR Lestrarbækur). 
Okt.: Íslendsk málfræði: aptur að kvennkynsorðunum.

Nóv:: Íslenzk málfræði: aptur í aðjektíva.

Des.: Íslenzk málfræði: búnir með Grammatíkina.

Feb.: Íslenzka: Búnir með nokkrar sögur í Fjölnir.

[strikað yfir $r$ í Fjölnir og tvístrikað undir!]

Marz: Íslenzka. Búnir með 9 ár, af Fjölnir. [leiðrétt á sama hátt]

Apríl: Íslenzka: búnir með Vopnfyrðinga sögu.

Maí: Íslenzka: lesið upp aptur málfræðina.

Næstu vetur var fjölbreytt lesefni í íslensku hjá Halldóri (MR Námsáætlanir). Í neðri bekkjunum var málfræði kennd eins og áður og í 1. bekk auk pess lesnar sögur í Lestrarbókinni og par lásu menn líka úr 9. árgangi Fjölnis, Vopnfirðinga sögu og Bandamanna sögu sem Halldór hafði annast útgáfu á. Í 2. bekk lásu nemendur Pórðar sögu hreðu, Bandamanna sögu og Fóstbræðra sögu, í 3. bekk var svo lesin Njáls saga og Grettis saga en í 4. bekk Gylfaginning, Háttatal, Skáldskaparmál og Sæmundar-Edda. Heimastílar og tímastílar voru gerðir vikulega. Próftími var prjár stundir fyrir ritgerðir og stíla en á pessum árum hófust einnig munnleg próf í íslensku (MR Stundaskrár).

\subsection{Skólastafsetningin}

Á fyrstu kennsluárum Halldórs Kr. Friðrikssonar mótaðist skólastafsetningin til fulls pó að kennslubókin, Íslenzkar rjettritunarreglur, kæmi ekki út fyrr en nokkrum árum síðar (Halldór Kr. Friðriksson 1859). Talið er að réttritunarreglur Halldórs megi rekja til samstarfs hans við Konráð Gíslason er peir unnu saman að útgáfu lokaárganga Fjölnis. Par notaði Konráð ritreglur sem að mestu studdust við uppruna orða en Jón Aðalsteinn Jónsson (1959:84-85) bendir á að pær kynnu að hafa orðið skammlífar hefðu pær ekki eignast „mjög ötulan stuðningsmann“, p.e. Halldór. Jón Aðalsteinn telur reyndar að Konráð og Halldór hafi í sameiningu mótað reglurnar sem Halldór kenndi síðan í eina framhaldsskóla landins í áratugi, pannig að pær hlutu að ráða miklu um stafsetningu lærðra manna pó að ýmsir peirra vildu fara aðrar leiðir. Helstu atriði réttritunarinnar voru pessi (að nokkru leyti í samantekt Jóns Aðalsteins Jónssonar (1959:86)): 
- Ritað var je en ekki é eða è alls staðar par sem svo var borið fram nema á eftir $g$ og $k$ en pó var ritað je í orðum eins og piggjendur.

- Grannur sérhljóði var ritaður á undan $n g$ og $n k$ samkvæmt fornu máli.

- Alls staðar var ritaður tvöfaldur samhljóði á undan priðja samhljóða par sem uppruni sagði til um.

- Alltaf var ritað $p$ en ekki fá undan $t$ (í sama atkvæði) og var par vikið frá uppruna.

- Reynt var að aðgreina í ritun mismunandi $æ$ eftir uppruna en pað náði ekki fótfestu og sést vart í stílum nemenda.

- Reglur um notkun y,ý og ey voru pær að leita skyldi uppruna orðmynda og huga að hljóðvörpum af $u, o, u ́, o ́$ og au við ritun peirra. Umfjöllun og dæmi um petta eru mjög fyrirferðarmikil hjá Halldóri (1859:75-137).

- Um ritun $z$ segir Halldór að hana skuli nota í stað $t s, d s$ eða ðs par sem „pessir stafir ættu að standa saman í sömu samstöfu, en kveðið er að, eins og s stæði“ (1859:183-187).

- Um ritun $n$ og $n n$ er einnig fjallað í löngu máli hjá Halldóri (1859:199-208) og hafa pær reglur haldist síðan.

\subsection{Ritgerðir vorið 1852}

Heillegt safn ritgerða frá 1852 er varðveitt (MR Próf) og hefur verið athugað nokkuð (Alda B. Möller 2014:63-67). Verkefnin voru skrifuð á litla miða og heiti lesið upp en utan um úrlausnir 4. bekkjar og 3.b. er strimill með áletruninni: „Íslenzkur stýll, 22 aðjunct Friðriksson, 23 Dr. Egilson, 24 aðjunct Sigurðsson“, og sýnir petta væntanlega að stílarnir gengu með dags bili milli kennarans og prófdómenda, peirra Sveinbjarnar Egilssonar og Jens Sigurðssonar. ${ }^{19}$ Prír menn lásu pví ritgerðirnar áður en einkunn var gefin. Ritgerðarefnin voru pessi:

Í 4. bekk og 3.b.: „Í hverju er hjátrú fólgin? Hverjar eru afleiðingar hennar? Og með hverju á að bægja henni burtu?“

Í 3.a.: „Hví ferst góður ásetningur svo opt fyrir?“

Í 2. bekk: „Hvaða not hafa menn af hestunum?“

19 Sveinbjörn Egilsson var sestur í helgan stein pegar hér var komið sögu en hann lést aðeins tveimur mánuðum síðar. 
Í ritgerðunum má sjá athugasemdir Halldórs. Hann skrifaði ekki inn leiðréttingar en strikaði undir villur - prisvar undir verstu villurnar! Reglum um stafsetningu varð að hlýða en hann gerði líka margar athugasemdir um málfar og greinarmerkjasetningu. Honum líkaði ekki að sjá danska tökuorðið kannske og hann amaðist við orðunum mögulegur og ómögulegur. Hann vildi ekki sjá orðið maður notað sem óákveðið fornafn og er víða strikað undir slíkt í ritgerðum. Aukaorð í tengingum voru illa séð og alltaf strikað undir að ef skrifað var ef að. Villur í greinarmerkjasetningu voru algengar og er pá yfirleitt merkt við vegna pess að kommur vantaði. Pær áttu greinilega að vera á undan öllum samtengingum - og reyndar miklu víðar.

Halldór kenndi forna beygingu ija-stofna karlkynsnafnorða og vildi pví t.d. ekki sjá orðmyndina flýtir í pf. eða pgf. Hann strikaði líka undir orðmyndir sem hugsanlega voru mállýskubundnar, t.d. merki um svonefndan $d$-framburð (heirdu) og hann strikaði undir sagnmyndirnar kóm og vóru. Pá strikaði hann alltaf undir ýmsar kringdar myndir spurnarorða og fornafna, t.d. hournin, hvornin, hour, aungu, aungvu en pær átti að skrifa hvernig, hver og engu. Fyrir kom að menn skrifuðu ötluðu í stað ætluðu og var prístrikað undir pað, líklega til marks um grófa villu.

Margt purfti að villumerkja í stílum 1. bekkinga. Fyrir kom að menn höfðu ekki tileinkað sér fyllilega bókstafinn ð (rád, tekid, med) og oft purfti að leiðrétta nafnorðsmyndina köttnum. Pá var framgómmælt $g$ og $k$ oft ritað gj og $k j$ (gjætu, kjettinum), og ei skrifað í stað $e$ á undan ng (eingin, heingja, heyngja). Nýnemar höfðu lítil tök á n/nn-reglunum (orsökinn, hálsin, köttin) og greinarmerkin hjá peim voru gloppótt.

Allt breyttist petta undir ",heraga“ Halldórs pegar nemendur klifu upp bekkjastigann; engin merki um beygingarvillur og afar fáar stafsetningarvillur er að finna í ritgerðum efstu bekkinga vorið 1852.

\section{Samantekt og lokaord}

Skólastjórnarráðið í Danmörku, sem var æðsta yfirvald Bessastaðaskóla, gerði frá upphafi ráð fyrir íslenskukennslu í skólanum og benda gögn til að hún hafi átt að eiga sama sess í skólastarfinu og móðurmálskennslan í dönskum skólum. Í Bessastaðaskóla átti að kenna íslensku í prjá tíma í hvorum bekk og af fyrirmælum mátti ráða að kenna skyldi ritun, málfræði og bókmenntir á pjóðtungunni.

Bessastaðaskóli starfaði í rétt rúmlega 40 ár en húsnæðið var 
frá upphafi ætlað til bráðabirgða enda vanbúið og of pröngt til að skólinn gæti starfað samkvæmt fyrirmælum yfirvalda. Рað var helsta brotalömin í stjórnun skólans og stóð honum einnig mest fyrir prifum í faglegum efnum. Á kennaraskort reyndi varla pví að aðeins voru tvær kennslustofur í skólanum og pví ekki rúm fyrir fleiri kennara. Fullyrða má að íslenskukennslan hafi liðið mjög fyrir pessi vandræði og pau komu líka í veg fyrir kennslu í ýmsum öðrum greinum. Latína, gríska og trúfræðigreinar voru burðarásar starfsins og í skugga peirra stóðu aðrar greinar alla tíð. Góður vilji yfirvalda dugði ekki til framfara í kennslumálum pví að getu og röggsemi til verklegra framkvæmda skorti.

Skýrslur kennara geyma sögu kennslunnar á Bessastöðum og margt fleira. Pær sýna að íslenskukennsla hófst af nokkrum metnaði haustið 1806 og greina fyrstu skýrslur frá stílæfingum, námi í íslenskum bókmenntum og málfræði, prjá tíma vikulega í hvorum bekk. Fljótlega hófst pó undanhaldið í efri bekk að beiðni nemenda og kennarans á peirri forsendu að par sætu fullorðnir menn sem væru vel að sér í móðurmálinu og pyrftu heldur að læra pýsku og landafræði. Pegar svo stærðfræðin fékk aukið rými í stundaskránni 1822 var íslenska sem námsgrein endanlega útilokuð úr efri bekk til loka skólans. Kennslan fólst í áratugi mest í pýðingum úr dönskum og latneskum lestrarbókum og uppistaða námsins var stílagerð en stundum var pó fjallað um íslenskar bókmenntir. Íslenskt mál var leiðrétt hvað varðaði almenna málnotkun en allt bendir til að stafsetning hafi verið mjög margbreytileg á pessum tíma. Lestrarbækurnar fyrir íslensku stílana voru flestar 18. aldar bókmenntir en nýútkomin íslensk tímarit og tímamótaverk á íslensku voru frekar notuð í dönskukennslu eða latínunáminu hjá sömu nemendum.

Á nútímamáli yrði málakennslan í Bessastaðaskóla líklega kölluð pverfagleg og víst er að íslenskunámið fór ekki aðeins fram í tímum í íslenskum stíl heldur ekki síður í latínu- og grískutímum, og jafnvel líka dönsku- og sögutímum. Ástæðan var að hluta til sú að pýddar námsbækur, sem Skólastjórnarráðið gerði ráð fyrir að yrðu prentaðar, urðu ekki að veruleika, heldur hlaut hver kennari að pýða kennsluefni sitt á íslensku í tímunum og nemendur að skrifa niður. Раð varð í raun gæfa skólans pví að allar heimildir herma að par hafi miklir málvöndunarmenn verið að verki, einkum peir Sveinbjörn Egilsson, sem kenndi grísku, sögu og dönsku, og Hallgrímur Scheving sem kenndi latínu.

Náminu í Bessastaðaskóla má líklega einnig lýsa með pvíað par hafi 
verið sáð í frjósaman akur sem leiddi til mikilla breytinga á íslensku máli. Margir nemendur skólans urðu pekktir menn og vönduðu mál sitt en áhrifamestir urðu sennilega peir Jónas Hallgrímsson skáld og Konráð Gíslason málfræðingur. Uppskera námsins var ný málviðmið með áherslu á málvöndun í orðavali og stíl en með rætur í forna málinu. Víst er að erlend orð áttu litlu fylgi að fagna í skólanum pó að pau slæddust með en á Bessastöðum bjuggu nemendur í sérstöku málfarslegu umhverfi sem lærifeðurnir höfðu skapað.

Við upphaf starfs Reykjavíkurskóla, sem oftast var nefndur Lærði skólinn, urðu straumhvörf í kennslu íslensku sem sérstakrar námsgreinar. Reglugerðir kváðu á um stöðu íslensku í skólastarfinu, inntak kennslunnar og framkvæmd prófa. Kennslustundum fjölgaði, námsefnið varð fjölbreyttara og kröfur til kennara og nemenda jukust.

pegar íslenska var loks orðin að eiginlegri námsgrein í skólastarfi hérlendis hófst skipuleg kennsla í íslenskri málfræði og íslenskum bókmenntum og par má greina upphaf samræmdrar stafsetningar. Réttritun málsins var að mótast um pað leyti sem Reykjavíkurskóli tók til starfa og skólastílar sýna að sú próun var hafin undir handleiðslu Sveinbjarnar Egilssonar. Hjá honum lærðu nemendur greinarmerkjasetningu og peir lærðu að vanda setningar og beygingar orða en fyrst og fremst áttu peir að forðast erlend áhrif í málnotkun og urðu að vanda orðaval. Með nemendum leitaði Sveinbjörn nýyrða og leiða til að tjá ný hugtök í málinu eða orða hugsun á hnitmiðaðan hátt.

Önnur tímamót urðu pegar Halldór Kr. Friðriksson gerðist kennari við skólann 1848 en hann tók íslenskukennsluna föstum tökum frá byrjun og kenndi í nær hálfa öld. Hann samdi kennslubækur í málfræði og réttritun og nemendur lásu bæði fornbókmenntir og samtímaskáldskap. Lestrarbækur nemenda bera pess einnig merki að hvergi var slegið af í lestri málfræði og íslenskra bókmennta. Reglum skólans um réttritun var fylgt fast eftir í tíð Halldórs enda jafnan kenndar við hann eða nefndar skólastafsetningin. Ritgerðir frá fyrstu árum skólans sýna að fátt var lengur aðfinnsluvert í ritmáli hjá elstu nemendum hans.

Gögnin benda til að um 1850 hafi ýmsir pættir málstaðalsins verið að mótast og ritmálið að breytast ört. Ritreglur með stoð í forna málinu festust pá í sessi meðal peirra sem stunduðu nám í skólanum. Pær urðu textaviðmið fram undir aldamótin 1900 og eru að flestu leyti enn. 


\section{Heimildir}

Aðalgeir Kristjánsson. 2003. Síðasti Fjölnismaðurinn: \#vi Konráðs Gíslasonar. Reykjavík: Skrudda.

Aðalgeir Kristjánsson 2005. Bessastaðaskóli: tveggja alda minning. Andvari 130:53-74.

Alda B. Möller. 2014. Íslenskukennsla í Bessastaðaskóla og á fyrstu árum Reykjavíkurskóla 1805-1855. BA-ritgerð í Háskóla Íslands. Skemman.is, http:// hdl.handle.net/1946/17696

Benedikt Gröndal. 1923. Dægradvöl: æfisaga mín. Reykjavík.

Björn K. Pórólfsson. 1925. Um íslenskar orđmyndir á 14. og 15. öld og breytingar peirra úr fornmálinu. Reykjavík: Málvísindastofnun Háskóla Íslands.

Dansk Biografisk Leksikon 4. 1979-1984. 3. útg. Ritstj. Sv. Cedergreen Bech. Kaupmannahöfn: Gyldendal.

Einar Ol. Sveinsson. 1942. Sveinbjörn Egilsson: 150 ára minning. Helgafell 1, 3:116-122.

Engelstoft, Laurits (ritstj.). 1806-1813. Universitetets og Skole-Annaler 18061813. Kaupmannahöfn: Directionen for Universitetet og de lærde Skoler.

Gísli Brynjúlfsson og Jón Pórðarson. 1848. Formáli. Norðurfari 1:iii-viii.

Halldór Kr. Friðriksson. 1846. Islandsk Læsebog med Ordregister og en Oversigt over den islandske Formlære. Kaupmannahöfn: Jægers Skandinaviske Forlagshandel.

Halldór Kr. Friðriksson. 1859. Íslenzkar rjettritunarreglur. Reykjavík: Hið íslenzka bókmenntafjelag.

Halldór Kr. Friðriksson. 1861. Íslenzk málmyndalýsíng. Kaupmannahöfn: Hið íslenzka bókmentafèlag.

Haukur Hannesson, Páll Valsson og Sveinn Yngvi Egilsson (ritstj.). 1989. Ritverk Jónasar Hallgrímssonar II. Bréfog dagbækur. Reykjavík: Svart á hvítu.

Heimir Porleifsson (ritstj.). 1975. Saga Reykjavíkurskóla. I. Reykjavík: Bókaútgáfa Menningarsjóðs.

Jón Árnason. 1952. Æfisaga Sveinbjarnar Egilssonar. Ljóðmæli Sveinbjarnar Egilssonar. 2. útg., bls. 1-50. Snorri Hjartarson gaf út. Reykjavík: Mál og menning.

Jón Árnason. 1862. Registur yfir bókasafn hins lærða skóla í Reykjavík. Reykjavíkurskóli.

Jón Jónsson. 1841. Skírsla um Bessastada-Skóla fyrir skólaárið 1840-1841. Skólaskýrslur 1840-46. Bessastaðaskóli.

Jón Jónsson. 1843. Skírsla um Bessastada-Skóla fyrir skólaárið 1842-1843. Skólaskýrslur 1840-46. Bessastaðaskóli.

Jón Aðalsteinn Jónsson. 1959. Ágrip af sögu íslenzkrar stafsetningar. Íslenzk tunga 1:71-119.

Jón Porkelsson. 1947. Merkir Íslendingar. Porkell Jóhannesson bjó til prentunar. Reykjavík: Bókfellsútgáfan. 
Kjartan G. Ottósson. 1990. Íslensk málhreinsun. Sögulegt yfirlit. Reykjavík: Íslensk málnefnd.

LS 6 = Lovsamling for Island: 6, 1792-1805. 1856. Oddgeir Stephensen og Jón Sigurðsson tóku saman og gáfu út. Kaupmannahöfn.

LS 7 = Lovsamling for Island: 7, 1806-1818. 1857. Oddgeir Stephensen og Jón Sigurðsson tóku saman og gáfu út. Kaupmannahöfn.

LS 13 = Lovsamling for Island: 13, 1844-1847. 1866. Oddgeir Stephensen og Jón Sigurðsson tóku saman og gáfu út. Kaupmannahöfn.

LS 14 = Lovsamling for Island: 14, 1848-1850. 1868. Oddgeir Stephensen og Jón Sigurðsson tóku saman og gáfu út. Kaupmannahöfn.

Magnús Grímsson. 1926. Úrvalsrit. Hallgrímur Hallgrímsson bjó til prentunar. Reykjavík.

Páll Melsteð. 1912. Endurminníngar Páls Melsteðs, ritaðar af honum sjálfum. Kaupmannahöfn: Hið íslenzka fræðafjelag.

Páll Eggert Ólason. 1948. Íslenzkar æviskrár I. Reykjavík: Hið íslenzka bókmenntafélag.

Páll Eggert Ólason. 1949. Íslenzkar æviskrár II. Reykjavík: Hið íslenzka bókmenntafélag.

Páll Eggert Ólason. 1950. Íslenzkar æviskrár III. Reykjavík: Hið íslenzka bókmenntafélag.

Páll Valsson. 1996. Íslensk endurreisn. Íslensk bókmenntasaga III, bls. 219-406. Reykjavík: Mál og menning.

Reykjavíkurpósturinn. 1846-1847. Reglugjörð um latínuskólann í Reykjavík.

Rosted, Jacob. 1806. Modersmaalet betragtet som en vigtig Deel af den studerende Ungdoms Underviisning i Skolerne. Universitetets og SkoleAnnaler 1806-1813. Ritstj. Laurits Engelstoft. Kaupmannahöfn: Directionen for Universitetet og de lærde Skoler.

Sigurður Gunnarsson. 1864. Æffiminning séra Guttorms Pálssonar, prófasts i Suður-Múlasýslu og prests á Hólmum í Reyðarfirði og Vallanesi á Völlum. Akureyri: B. M. Stephánsson.

Skólaræður Sveinbjarnar Egilssonar. 1968. Haraldur Sigurðsson sá um prentun. Reykjavík: Almenna bókafélagið.

Svavar Pór Guðmundsson. 1997. Bessastaðaskóli 1805-1846. BA-ritgerð í sagnfræði. Háskóli Íslands.

Sveinbjörn Egilsson. 1829-1840. Odysseifs-drápa í pýðingu Sveinbjarnar Egilssonar. Bodsrit Bessastada skóla: 1.-2. bók 1829, 3.-4. bók 1830, 5.-8. bók 1835, 9.-12. bók 1838, 13.-16. bók 1839, 17.-20. bók 1840 og 21.-24. bók 1840. Bessastaðaskóli.

Sveinbjörn Egilsson. 1847. Skólaskýrsla fyrir Reykjavíkur lærða Skóla árið 184647. Reykjavík: Lærði skólinn.

Sveinbjörn Egilsson. 1848. Skólaskýrsla fyrir Reykjavíkur lærða skóla árið 184748. Reykjavík: Lærði skólinn.

Sveinbjörn Egilsson. 1849. Skólaskýrsla fyrir Reykjavíkur lærða skóla árið 184849. Reykjavík: Lærði skólinn. 
Sveinbjörn Egilsson. 1851. Skólaskýrsla fyrir Reykjavíkur lærða skóla árið 185051. Reykjavík: Lærði skólinn.

Sveinn Pálsson (pýð.). 1789. Um pá organisku hluti á jarðarhnettinum. Rit pess íslenzka lærdómslistafélags 10:175-264.

Wolf, Christian A. 1977. Sveinbjörn Egilsson's grammatical writings in Lbs. 456 4to: An edition and commentary with special reference to Rask. Ph.D. thesis, Dept. of Germanic Languages, University of North Carolina.

Yelverton, John R. 1971. The first grammar of Icelandic in the native tongue. An edition of Lbs. 1238 8vo, and an investigation of its sources. Ph.D. thesis, Dept. of Germanic Languages, University of North Carolina.

\section{Óprentaðar heimildir}

Árni Thorsteinsson. Án ártals. Minningar úr Bessastaðaskóla. Óprentuð ritgerð. Einar G. Pétursson annaðist frágang.

Árni Thorsteinsson. Án ártals. Lbs. 2429 4to. Landsbókasafn Íslands.

Bps. = Biskupsskjalasafn, Bps. C. VII. Bréf til biskups eða stiftisyfirvalda um Bessastaðaskóla. Pjóðskjalasafn Íslands.

Bps. 1a, Bps. 1b, Bps. 2a, Bps. 2b, Bps. 3a, Bps. 4b, Bps. 5a, Bps. 5b, Bps. 6a, Bps. 6b, Bps. 7a, Bps. 7b, Bps. 8a, Bps. 8 b.

Guttormur Pálsson (?). Án ártals. Lbs. 1238 8vo. Landsbókasafn Íslands. ÍB. 50 fol. Safn sendibréfa til Laurits Engelstoft. Landsbókasafn Íslands. KG 31.a.1. Skjalasafn Konráoss Gíslasonar. Stofnun Árna Magnússonar í íslenskum fræðum.

Magnús Grímsson. 1847. Lbs. $1098 v o$ a. Landsbókasafn Íslands.

MR Lestrarbækur $=$ M.R. Lestrarbækur 1851-1868. . jóðskjalasafn Íslands.

MR Námsáætlanir $=$ M.R. Námsáætlanir o.p.h. 1851-1871. Pjóðskjalasafn Íslands.

MR Próf = M.R. Skrifleg próf 1847-1848, 1852. Pjóðskjalasafn Íslands.

MR Stundaskrár = M.R. Stundaskrár og próftöflur 1851-1893. Pjóðskjalasafn Íslands.

Sk. = Skjalasafn skólastjórnarmála . Pjóðskjalasafn Íslands.

Sk. 1-14, Sk. 1-41, Sk. 2-8, Sk. 3-26, Sk. 5-1, Sk. 5-10, Sk. 5-15, Sk. 6-1, Sk. 6-9, Sk. 6-10, Sk. 7-3, Sk. 7-4, Sk. 8-17, Sk. 12-1, Sk. 13-1.

Sveinbjörn Egilsson. Án ártals. Lbs. 456 4to. Landsbókasafn Íslands.

\section{Lykilorð}

Bessastaðaskóli, Reykjavíkurskóli, námsefni og kennsla í íslensku, málstýring, málstöðlun, stafsetning

\section{Keywords}

Bessastaðir School, Reykjavik Grammar School, curriculum and teaching of Icelandic, language planning, standardisation, orthography 


\begin{abstract}
The school at Bessastaðir in Iceland (1805-1846) prepared students for the clergy and further studies at the University of Copenhagen. Despite its emphasis on classical languages and theological studies it is considered to have had considerable influence on the development of the Icelandic language and language norms in the 19th century. The article discusses the status of the Icelandic language in the school curriculum but it also highlights the multi-disciplinary nature of language instruction through translations from Greek and Latin under the supervision of renowned experts in Old Icelandic who also were keen supporters of Icelandic language vocabulary development. Many able students built on this experience to pioneer the development of Modern Icelandic.

Icelandic lessons in the Bessastaðir School timetable consisted of translations from Latin and Danish with less emphasis on literature; some attention was paid to grammar while orthography varied. The school was cramped and the building not fit for purpose. This state of affairs prevailed until the school moved to Reykjavik in 1846, which opened up great possibilities. Finally, teaching of modern languages, including Icelandic, could be developed in the curriculum.

Timetables in the Reykjavik Grammar School show increased emphasis on the subject Icelandic, both in number of hours and variety of content. Teaching of the subject was prescribed by official regulations and included Icelandic grammar as well as modern and medieval literature. Standardised orthography was developed and firmly established in the early years of the school by rules that were largely based on Old Icelandic. These rules are still mostly applicable in modern day Icelandic texts. The article describes these developments in the first few years of the Reykjavik Grammar School, largely based on the school's archives and significant essay material from students at the time.
\end{abstract}

Alda Bryndís Möller

MA-nemi í íslensku

Hjallabrekku 6

200 Kópavogur

aldam@outlook.com 